\title{
SUBDUCTION-INDUCED PORE FLUID VENTING AND THE FORMATION OF AUTHIGENIC CARBONATES ALONG THE CASCADIA CONTINENTAL MARGIN: IMPLICATIONS FOR THE GLOBAL Ca-CYCLE
}

\author{
M. W. HAN ${ }^{1}$ and E. SUESS ${ }^{2}$ \\ College of Oceanography, Oregon State University, Corvallis, OR 97331 (U.S.A.)
}

(Received October 27, 1987; revised and accepted May 24, 1988)

\begin{abstract}
Han, M. W. and Suess, E., 1989. Subduction-induced pore fluid venting and the formation of authigenic carbonates along the Cascadia continental margin: Implications for the global Ca-cycle. Palaeogeogr., Palaeoclimatol., Palaeoecol., 71: 97--118.

Pore fluid venting associated with subduction-induced sediment deformation causes precipitation of calcium carbonate as prominent carbonate chimneys or cement in the accreted sediments across the active continental margin off Oregon and Washington. A depletion of interstitial $\mathrm{Ca}^{2+}$ with a maximum decrease of $50 \%$ relative to seawater $\mathrm{Ca}^{2+}$ over only $1.5 \mathrm{~m}$ depth and reduction in porosity in the deformed sediments suggest that interstitial $\mathrm{Ca}^{2+}$ is removed to form calcium carbonate cement. In contrast, the pore waters of the undeformed abyssal plain sediments show no depletion in dissolved $\mathrm{Ca}^{2+}$. They are either enriched to a maximum of $5 \%$ or show no change in dissolved $\mathrm{Ca}^{2+}$. Here the background level of $\mathrm{CaCO}_{3}$ content in the sediment is only 0.1 to $1 \%$.

Calcium carbonate precipitation in the deformed sediments probably occurs as the result of upward migration and oxidation of biogenic methane and of the increase in carbonate saturation due to release of excess pore pressure during fluid venting. Upward advection of fluids at rates of $1-28 \mathrm{~cm} \mathrm{y}^{-1}$ is predicted from diffusion-advection-reaction models applied to the downcore concentration profiles of dissolved $\mathrm{Ca}^{2+}$ and $\mathrm{NH}_{4}{ }^{+}$in the tectonically-deformed sediments. The range of predicted flow rates is related to the type of calcium carbonate lithification; i.e. slow rates generate cement and fast rates generate chimneys.

Carbonate mineral precipitation associated with pore fluid venting requires direct transfer of $\mathrm{Ca}^{2+}$ from the oceanic basement to the accretionary complex. Such a mechanism leads us to propose that the accretionary complexes of the global plate subduction zones are a major sink for crustal $\mathrm{Ca}^{2+}$. A global flux of crustal $\mathrm{Ca}^{2+}$ that is removed by carbonate mineral precipitation may be as much as the hydrothermal Ca-input. This significant Ca-flux, not previously considered in the global geochemical budget, implies that pore fluid venting in subduction zones may also act as a global sink or source for other elements.
\end{abstract}

\section{Introduction}

Recent discoveries of carbonate chimneys and benthic communities of tube worms and

\footnotetext{
${ }^{1}$ Present address: Korea Ocean Research and Development Institute, Seoul H25-600 (Korea).

${ }^{2}$ Present address: GEOMAR Research Center, Wischhofstr. 1- 3 D-23 Kiel 14 (F.R.G.).
}

giant clams associated with pore fluid venting in the accretionary complexes of subduction zones (Suess et al., 1985; Kulm et al., 1986; Schroeder et al., 1987; Boulegue et al., 1987; Cadet et al., 1987; LePichon et al., 1987; Ohta and Laubier, 1987; Pautot et al., 1987) suggest a new mechanism that may affect the global seawater composition. Advecting pore fluid through the accreted sediments would exchange and transfer elements between the 
subducting crust and the ocean water. One could foresee an important role of pore fluid venting at global subduction zones on the chemical mass balance of the oceans if the areal extent of fluid venting and the magnitude of mass transfer can be established. Although it is unclear at present if subduction-induced transport by fluid venting is similar in magnitude to that of mid-ocean ridge hydrothermal fluxes, both are ultimately related to the major tectonic processes of plate generation and consumption.

Calcium carbonate precipitation and cementation of near-surface sediments associated with pore fluid venting occurs not only in the accretionary complex of the northeast Pacific but also along several other convergent margins: the Barbados accretionary complex (Moore et al., 1986), the Nankai Trough sediments (Stein and Smith, 1986), and the Peru convergent margin (Kastner et al., 1987). This world-wide distribution suggests to us the need for a revision of the global Ca-balance (Thompson, 1983; Von Damm et al., 1985) by including - as a first approximation subduction-induced calcium carbonate precipitation as a major sink for calcium.

Since prominent carbonate chimneys and crusts in the Cascadia accretionary complex off Oregon/Washington are associated with venting pore fluids, an understanding of the geochemical condition of the calcium carbonate system of the interstitial waters is essential in order to explain the formation of the pervasive carbonate lithification. Interstitial $\mathrm{Ca}^{2+}$ in near-surface sediments is in general controlled by biogeochemical processes of organic matter decomposition which generates an excess of dissolved $\Sigma \mathrm{CO}_{2}$. Carbonate precipitation, as oposed to dissolution in pelagic environments, was observed in hemipelagic environments of rapid burial of sediments rich in organic matter (Moor and Gieskes, 1980; Suess et al., 1982; Kawahata and Fujioka, 1986; Stein and Smith, 1986).

The Cascadia accretionary complex receives hemipelagic sediments from the Columbia River drainage basin and the weathering of the
Coast Range at a fairly rapid rate of around $10 \mathrm{~cm}$ per 1000 y (Karlin, 1979; Krissek, 1982). Characteristically these sediments are extremely low in detrital and biogenic calcium carbonate. Therefore, the carbonates in the accretionary complex are not due to deposition but are the result of dynamic control on the dissolved calcium carbonate system associated with pore fluid venting. Moreover, the morphology and shape of the chimneys, crusts, concretions and interstitial cements strongly support an authigenic mechanism of formation (Scamman, 1981; Ritger et al., 1987). Venting apparently provides favorable geochemical conditions for calcium carbonate authigenesis in the accretionary complex.

In this paper we investigate, based on chemical compositions of pore water from the Cascadia subduction zone, the mechanism of carbonate mineral precipitation associated with pore fluid venting. We then evaluate the potential role of this process in removing crustal $\mathrm{Ca}^{2+}$ and finally speculate on the implications for the global balance of $\mathrm{Ca}^{2+}$.

\section{Geologic setting and methods}

The Juan de Fuca oceanic plate, generated at the Juan de Fuca spreading Ridge, is presently being subducted off Oregon and Washington as it converges with the North American plate at a rate of $4 \mathrm{~cm} \mathrm{y}^{-1}$ (Wells et al., 1984) (Fig.1a). A portion of the sediments loaded on the subducting plate is off-scraped and added onto the overriding North American plate forming the Cascadia accretionary complex along the lower continental slope (Silver, 1972; Carson et al., 1974; Kulm and Fowler, 1974).

The accretionary complex consists of a series of folded and thrusted ridges trending perpendicular to the convergence direction (Silver, 1972; Carson et al., 1974; Kulm et al., 1986). The ridges become progressively older from the west to the east across the complex. The youngest ridges of the deformation front are less than $0.3 \mathrm{~m} . \mathrm{y}$. old and rise from 400 to $1000 \mathrm{~m}$ above the adjacent abyssal plain (Carson et al., 1974; Kulm et al., 1986). 


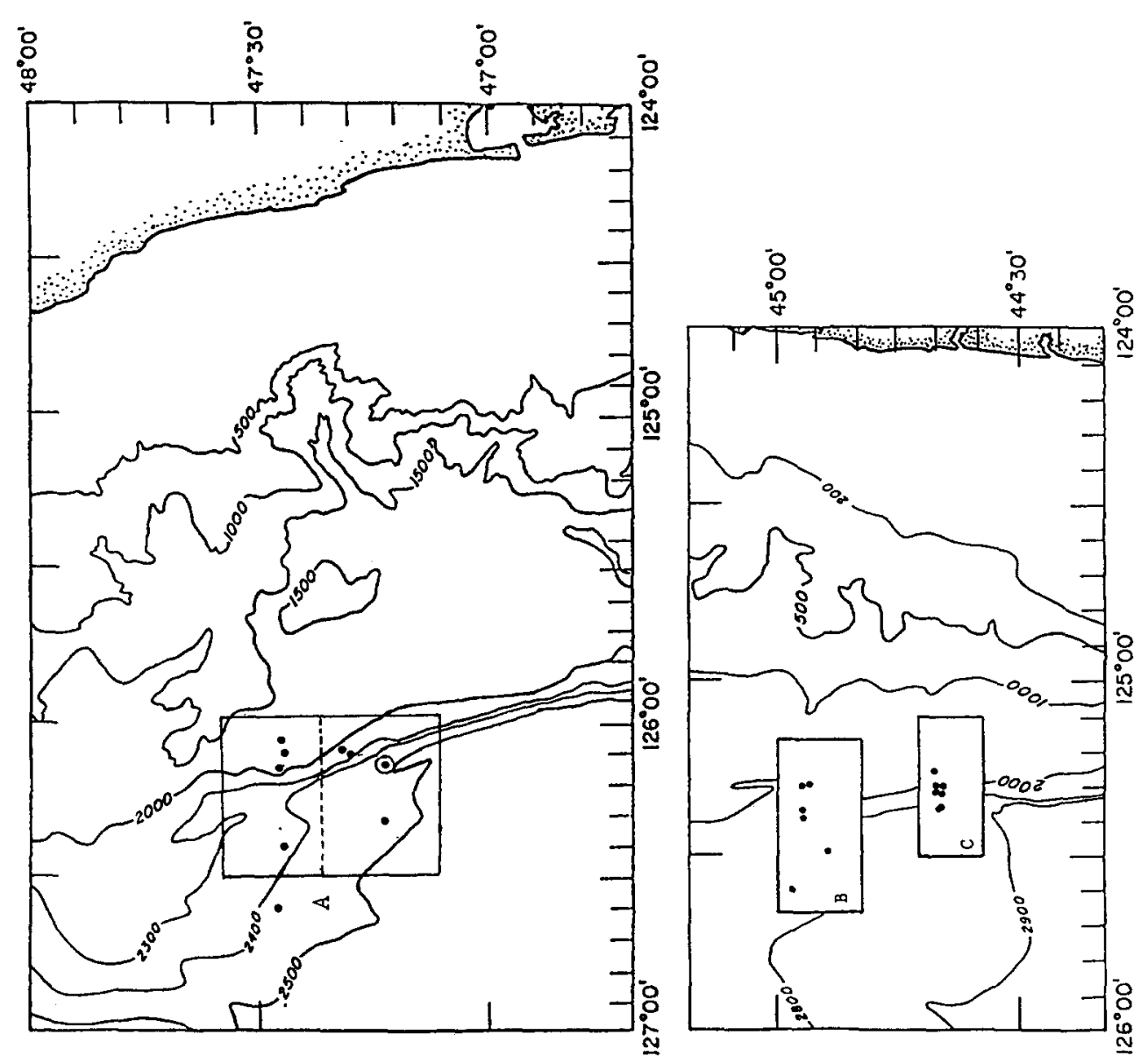

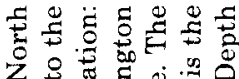

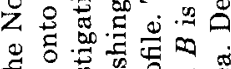

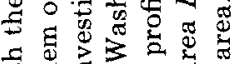

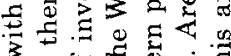
3 aot 형

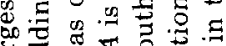

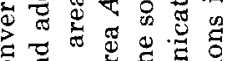

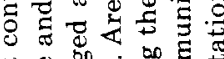

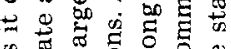

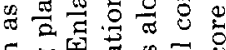

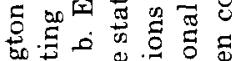

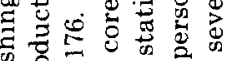
उ

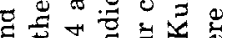

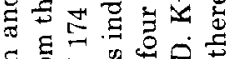

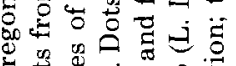

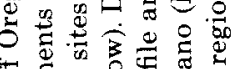

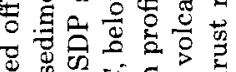

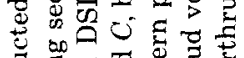

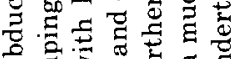

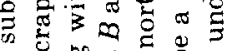

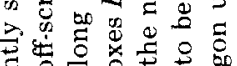

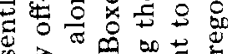

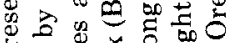

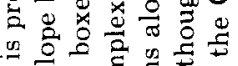
\pm क

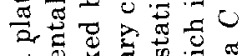

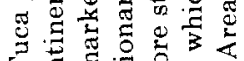
¿

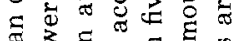
胥亭

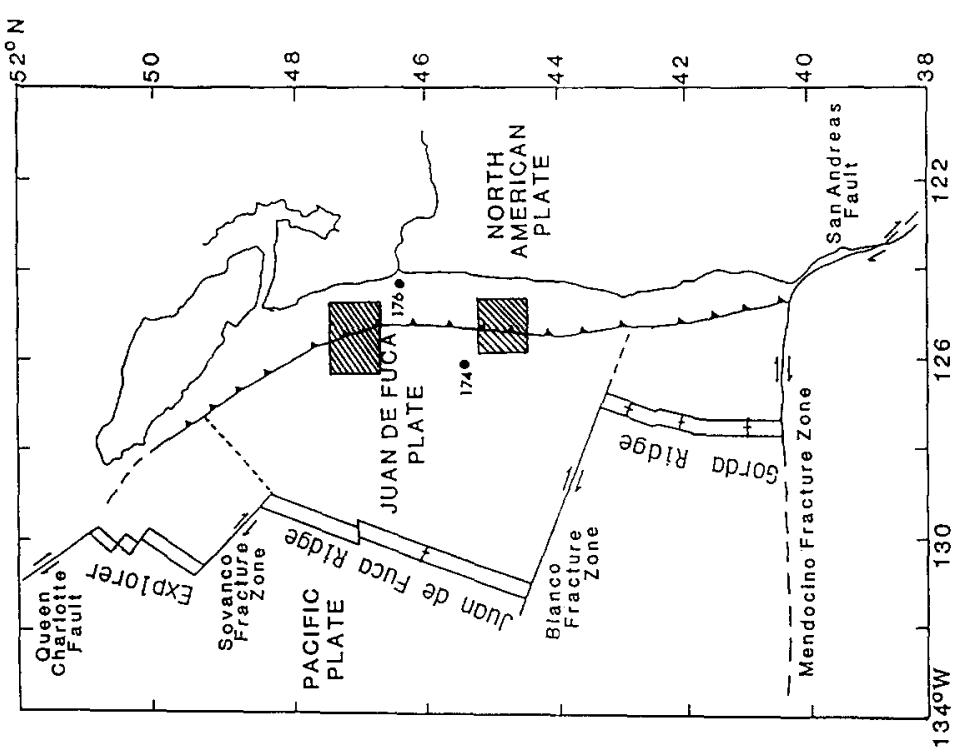

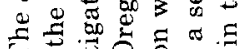
¿

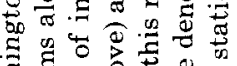
ส

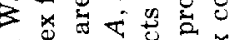
๘ ส है

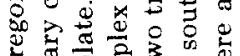
ڤँ

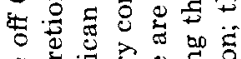

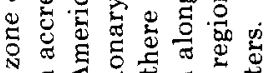

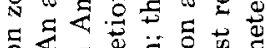

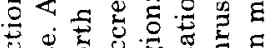

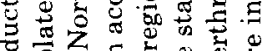

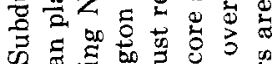

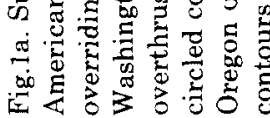


The mode of occurrence and the morphology of the carbonates in the accretionary complex are diverse: slabs, crusts, and disseminated cement are found throughout the near-surface sediments. Their mineralogies, isotopic compositions, and fabric have been extensively studied (Russell et al., 1967; Scamman, 1981; Ritger et al., 1987). Conical chimneys, 1-2 $\mathrm{m}$ in height protruding above the sea floor, were found associated with the benthic communities of tube worms and giant clams on the marginal ridge of the deformation front in the Oregon accretionary complex (Kulm et al., 1986). Other carbonate chimneys were discovered on the outermost continental shelf off northern Oregon (Schroeder et al., 1987).

Generally all carbonates are strongly depleted in the carbon isotope ${ }^{13} \mathrm{C}$. The depletion is characteristic of methane-derived calcium carbonates (Kulm et al., 1986; Suess et al., 1987; Suess and Whiticar, this issue). Pure carbonate precipitates which build up the chimney structures indicate an authigenic mode of formation. Hollow tubes and passages with numerous grooves and flutes within all the chimneys are thought to be the imprints of venting fluids (Schroeder et al., 1987).

Pore water samples and sediment cores were obtained from areas of carbonate lithification along four transects spanning the tectonic elements of the abyssal plain to the deformation ridges (Fig.1b). Coring was done during two geological/geophysical cruises, the first in June of 1983 on board the $R / V$ Wecoma and the second in August of 1984 on board the $R / V$ Atlantis II.

The northern transects (Box $A$ in Fig.1b) are in the central Washington overthrust area. They consist of five stations along a northern profile and four stations along a southern profile (Fig.2a). Combined these stations represent the abyssal plain environment (8306-9C,
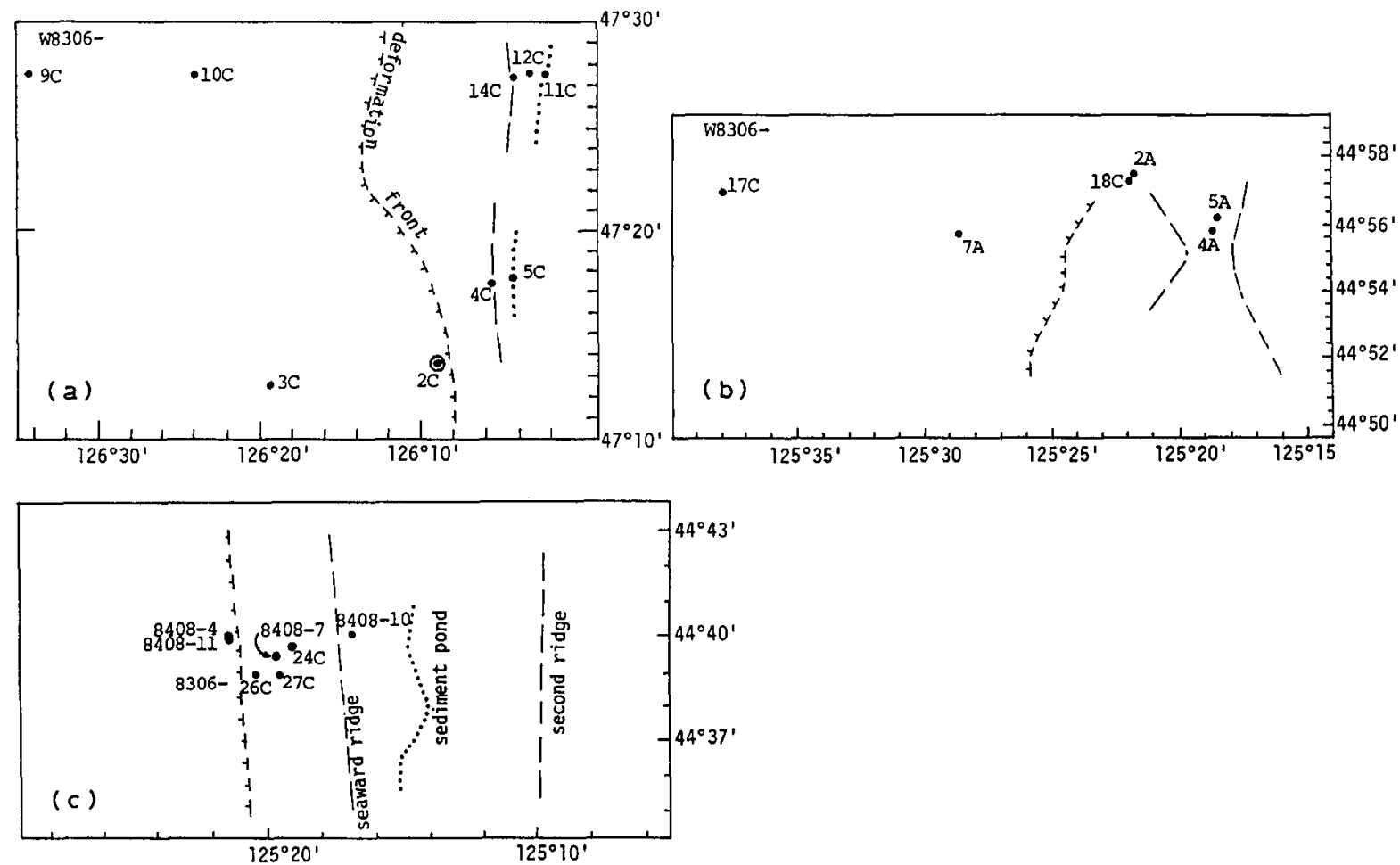

Fig.2. Locations of core stations from the Washington overthrust region $(a)$, the Oregon overthrust region (b), and the Oregon underthrust region $(c)$. Core locations are shown in relation to the tectonic elements of the accretionary complex, deformation front, seaward ridge, sediment pond, and second ridge. 
$-10 \mathrm{C}$ and $-3 \mathrm{C}$ ), the crest of the seaward deformation ridge (8306-4C), the ponded sediments behind this ridge (8306-12C and $-5 \mathrm{C}$ ), two morphologic features within the sediment pond (8306-14C $=$ moat and $8306-11 \mathrm{C}=$ mound), and a sea mount on the abyssal plain (8306-2C).

The central transect is in the Oregon overthrust area (Box $B$ in Fig.1b). Three of the tectonic elements were sampled (Fig.2b): the abyssal plain (8306-17C and $-7 \mathrm{~A})$, the crest of the seaward ridge (8306-2A and $-18 \mathrm{C}$ ), and the flanks of the second deformational ridge (8306$4 \mathrm{~A}$, and $-5 \mathrm{~A}$ ). No ponded sediment basin is developed here between the ridges.

The southern transect is in the Oregon underthrust area (Box $C$ in Fig.1b). Here the tectonic elements were cored in greater detail than in the overthrust area (Fig.2c). Two cores were taken just seaward of the deformation front which is evident in a scarp (8408-4, and -11), four cores were taken on the seaward flank of the deformational ridge. They range from the foot of the ridge (8306-26C), across several sedimented ledges (8306-27C, $-24 \mathrm{C}$ and $8408-7)$ to the landward side of the ridge, where the ponded sediments unconformably overlie the ridge flank (8408-10). Carbon isotope data of dissolved $\mathrm{\Sigma CO}_{2}$, pore water nutrients, and methane contents from this transect are the subject of a separate paper by Suess and Whiticar (this issue). All core locations and their tectonic environments are summarized in Table I.

TABLE I

Core locations in the Oregon/Washington subduction zone

\begin{tabular}{|c|c|c|c|c|}
\hline Station & $\begin{array}{l}\text { Latitude } \\
\left({ }^{\circ}\right)\end{array}$ & $\begin{array}{l}\text { Longitude } \\
\left({ }^{\circ} \mathrm{W}\right)\end{array}$ & $\begin{array}{l}\text { Water depth } \\
\text { (m) }\end{array}$ & Setting \\
\hline \multicolumn{5}{|c|}{$\begin{array}{l}\text { A. Central Washington overthrust area } \\
\text { Northern profile }\end{array}$} \\
\hline $8306-9 \mathrm{C}$ & $47^{\circ} 27.51^{\prime}$ & $126^{\circ} 34.55^{\prime}$ & 2370 & abyssal plain \\
\hline $8306-10 \mathrm{C}$ & $47^{\circ} 27.42^{\prime}$ & $126^{\circ} 23.89^{\prime}$ & 2320 & abyssal plain \\
\hline $8306-11 \mathrm{C}$ & $47^{\circ} 27.49^{\prime}$ & $126^{\circ} 02.15^{\prime}$ & 1600 & sediment pond behind seaward ridge \\
\hline $8306-12 \mathrm{C}$ & $47^{\circ} 27.47^{\prime}$ & $126^{\circ} 03.28^{\prime}$ & 1807 & mound in sediment pond \\
\hline $8306-14 \mathrm{C}$ & $47^{\circ} 27.50^{\prime}$ & $126^{\circ} 04.17^{\prime}$ & 1810 & moat behind seaward ridge \\
\hline \multicolumn{5}{|c|}{ Southern profile } \\
\hline $8306-2 \mathrm{C}$ & $47^{\circ} 13.70^{\prime}$ & $126^{\circ} 08.90^{\prime}$ & 2320 & sea mount on abyssal plain \\
\hline $8306-3 \mathrm{C}$ & $47^{\circ} 12.50^{\prime}$ & $126^{\circ} 19.36^{\prime}$ & 2445 & abyssal plain \\
\hline $8306-4 \mathrm{C}$ & $47^{\circ} 17.53^{\prime}$ & $126^{\circ} 05.67^{\prime}$ & 1920 & top of seaward ridge \\
\hline $8306-5 \mathrm{C}$ & $47^{\circ} 17.74^{\prime}$ & $126^{\circ} 04.29^{\prime}$ & 2050 & sediment pond behind seaward ridge \\
\hline \multicolumn{5}{|c|}{ B. Oregon overthrust area } \\
\hline $8306-2 \mathrm{~A}$ & $44^{\circ} 57.47^{\prime}$ & $125^{\circ} 21.87^{\prime}$ & 2376 & top of seaward ridge \\
\hline $8306-4 \mathrm{~A}$ & $44^{\circ} 55.91^{\prime}$ & $125^{\circ} 18.64^{\prime}$ & 2008 & flank of second ridge \\
\hline $8306-5 \mathrm{~A}$ & $44^{\circ} 56.26^{\prime}$ & $125^{\circ} 18.45^{\prime}$ & 1990 & flank of second ridge \\
\hline $8306-7 \mathrm{~A}$ & $44^{\circ} 52.82^{\prime}$ & $125^{\circ} 28.64^{\prime}$ & 2758 & abyssal plain \\
\hline $8306-17 \mathrm{C}$ & $44^{\circ} 57.00^{\prime}$ & $125^{\circ} 37.92^{\prime}$ & 2735 & abyssal plain \\
\hline $8306-18 \mathrm{C}$ & $44^{\circ} 57.45^{\prime}$ & $125^{\circ} 21.96^{\prime}$ & 2376 & top of seaward ridge \\
\hline $8306-21 \mathrm{C}$ & $44^{\circ} 56.10^{\prime}$ & $125^{\circ} 16.15^{\prime}$ & 1550 & top of third ridge \\
\hline \multicolumn{5}{|c|}{ C. Oregon underthrust area } \\
\hline $8306-24 \mathrm{C}$ & $44^{\circ} 39.78^{\prime}$ & $125^{\circ} 19.07^{\prime}$ & 2420 & foot of seaward ridge \\
\hline $8306-26 \mathrm{C}$ & $44^{\circ} 39.00^{\prime}$ & $125^{\circ} 20.50^{\prime}$ & 2795 & second ledge on seaward ridge \\
\hline $8306-27 \mathrm{C}$ & $44^{\circ} 39.00^{\prime}$ & $125^{\circ} 19.66^{\prime}$ & 2623 & first ledge on seaward ridge \\
\hline $8408-4$ & $44^{\circ} 40.00^{\prime}$ & $125^{\circ} 21.60^{\prime}$ & 2860 & abyssal plain \\
\hline $8408-7$ & $44^{\circ} 39.50^{\prime}$ & $125^{\circ} 19.70^{\prime}$ & 2550 & first ledge on seaward ridge \\
\hline $8408-10$ & $44^{\circ} 40.00^{\prime}$ & $125^{\circ} 17.10^{\prime}$ & 2180 & sediment pond behind seaward ridge \\
\hline $8408-11$ & $44^{\circ} 39.90^{\prime}$ & $125^{\circ} 21.50^{\prime}$ & 2846 & deformed abyssal plain \\
\hline
\end{tabular}


Pore waters were extracted from sediments by pressure filtration at the temperature of the bottom water $\left(2^{\circ} \mathrm{C}\right)$ with a technique of Hartmann et al. (1973). Dissolved ammonium was determined by standard methods for nutrient analyses in seawater (Grasshoff, 1976) and calcium by flame atomic absorption spectrophotometry. Dissolved $\Sigma \mathrm{CO}_{2}$ in pore water was acidified, helium-stripped and measured by online gas chromatography with a thermal conductivity detector. Availability of $\mathrm{pH}$ data only at two core stations (8306-2C and 8306-3C) restricted the estimation of carbonate saturation state to these stations. Carbonate carbon content was measured by $\mathrm{H}_{3} \mathrm{PO}_{4} /$ dichromateLECO technique described by Weliky et al. (1983).

Pore water chemistry data of the dissolved $\mathrm{NH}_{4}{ }^{+}$and $\mathrm{Ca}^{2+}$ were used for the estimation of vertical advection rates. Dissolved $\mathrm{\Sigma CO}_{2}, \mathrm{pH}$, and $\mathrm{Ca}^{2+}$ were used for the calculation of calcium carbonate saturation state of pore waters following the relations given by Skirrow (1975).

\section{Results}

Pore water $\mathrm{Ca}, \mathrm{CaCO}_{3}$ and water contents

Dissolved interstitial $\mathrm{Ca}^{2+}$ shows contrasting concentration profiles with depth across all transects of the accretionary complex (Fig.3): $\mathrm{Ca}^{2+}$ decreases significantly with depth, to a minimum of $50 \%$ of bottom water $\mathrm{Ca}^{2+}$ over only $1.5 \mathrm{~m}$ sediment thickness, in the coring stations located landward of the deformation front (crest and flanks of deformational ridges) while $\mathrm{Ca}^{2+}$ remains constant or increases with depth, to a maximum of $5 \%$ of oceanic bottom water $\mathrm{Ca}^{2+}$ over the same depth, in all stations from the abyssal plain and intra-basin sediments. The Ca-content in the pore waters of the sea mount located in the abyssal plain shows the strongest decrease.

Though depletion of interstitial $\mathrm{Ca}^{2+}$ in continental margin sediments has commonly been related to carbonate mineral precipitation (Watermann et al., 1972; Suess et al., 1982;
Stein and Smith, 1986), such a drastic depletion over only $1.5 \mathrm{~m}$ sediment thickness has, to our knowledge, not been reported before. The decrease in interstitial $\mathrm{Ca}^{2+}$ in the deformed sediments of the accretionary complex suggests significant carbonate mineral precipitation and cementation.

No change or enrichment of interstitial $\mathrm{Ca}^{2+}$ in the undeformed abyssal plain and intrabasin sediments indicates no significant carbonate mineral precipitation there. Measurements of $\mathrm{CaCO}_{3}$-content in sediments from selected stations show that more $\mathrm{CaCO}_{3}$ is contained in the deformed sediments $(2-5 \%)$ than is in the undeformed sediments $(0.1-1 \%)$ (Fig.4). Although we did not attempt to verify in detail the nature of these carbonates, we have obtained stable carbon isotope measurements of $-1.98 \%$ and $-3.07 \%$ PDB from two bulk sediment samples of the deformation ridge (Station 8306-21C with subsurface sample intervals, $15-20 \mathrm{~cm}$ and $30-35 \mathrm{~cm}$ ) with a total calcium carbonate content of 2.5 and $2.6 \mathrm{wt}-\%$, respectively. These data indicate the presence of some small portion of methane-derived authigenic $\mathrm{CaO}_{3}$ mixed with isotopically heavier biogenic $\mathrm{CaCO}_{3}$. Samples obtained with DSRV Alvin over the vent sites contain more $\mathrm{CaCO}_{3}$, ranging from 25 to $90 \%$, and greater amounts of methane-derived carbonates with $\delta^{13} \mathrm{C}$ values of between $-35 \%$ and $-67 \%$ PDB (Ritger et al., 1987).

The apparent dependence of the interstitial $\mathrm{Ca}^{2+}$ on sediment deformation is further confirmed by the relationship between the depth gradients of interstitial $\mathrm{Ca}^{2+}$ and water content. Figure 5 clearly shows that the depletion of interstitial $\mathrm{Ca}^{2+}$ coincides with the reduction in water content, whereas the enrichment of interstitial $\mathrm{Ca}^{2+}$ is observed in sediments whose water content changes little. Although expulsion of pore fluid, due to sediment deformation, is the dominant cause for the porosity reduction (Carson and Berglund, 1986), in situ carbonate mineral precipitation and the resulting cementation of sediments may in part cause porosity reduction as well, especially in near-surface sediments. 
$\mathrm{Ca}(\mathrm{mg} / \mathrm{l})$

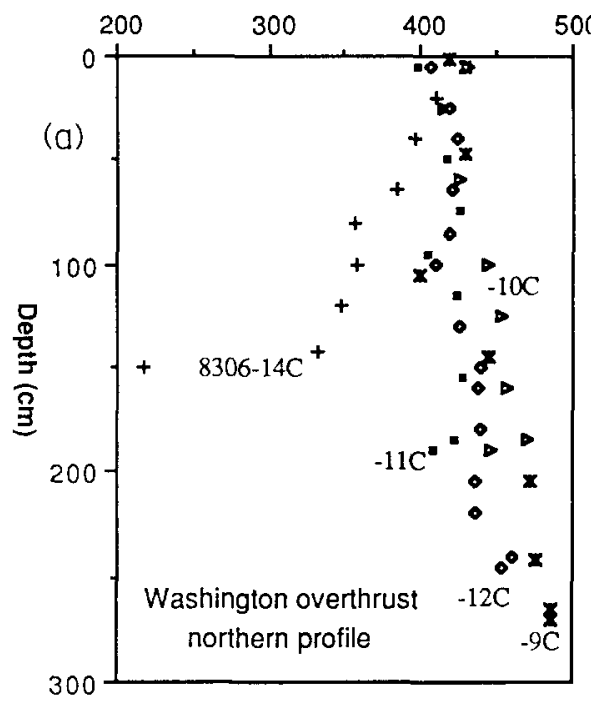

$\mathrm{Ca}(\mathrm{mg} / \mathrm{l})$

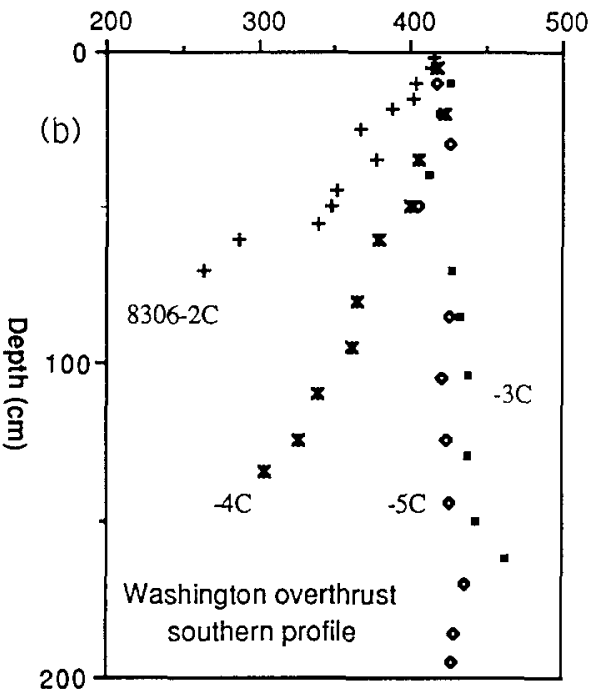

$\mathrm{Ca}(\mathrm{mg} / \mathrm{l})$
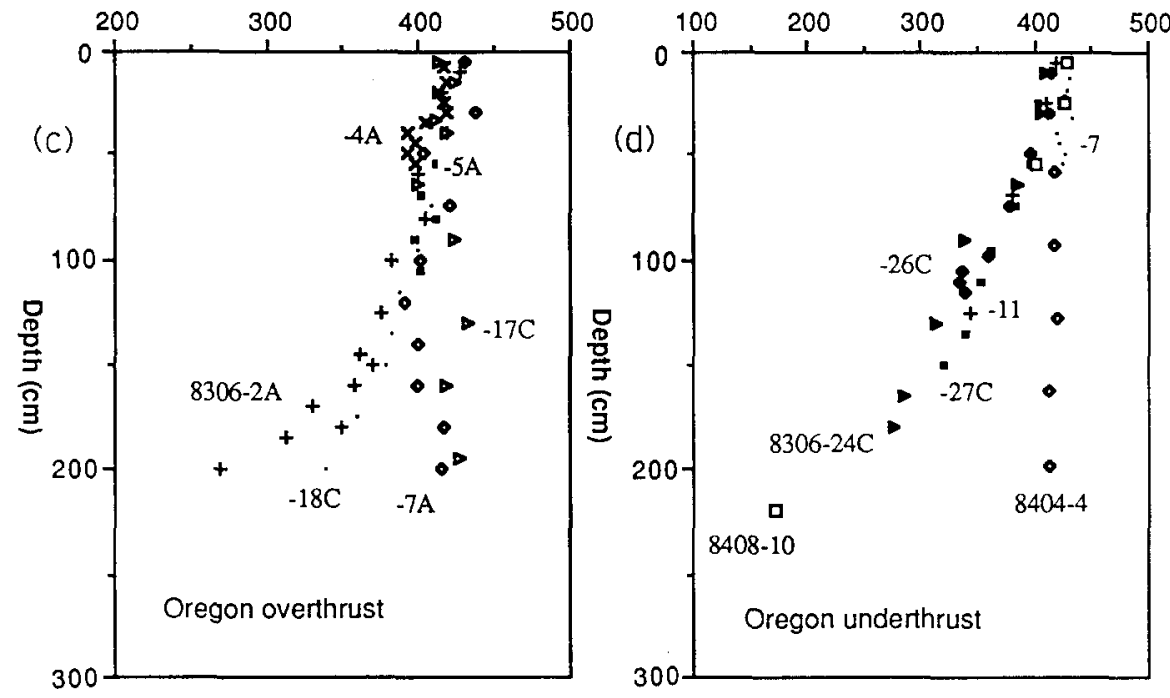

Fig.3. Depth profiles of interstitial Ca concentration for the cores from the northern $(a)$ and the southern $(b)$ profiles of the Washington overthrust, from the Oregon overthrust (c), and the Oregon underthrust (d). In general, interstitial Ca decreases with depth at core stations from deformed sediments and increases or remains constant at core stations from undeformed sediments; refer to Table I for further station identification.

All of these contrasting relationships observed between deformed, accreted sediments and undeformed abyssal plain sediments; i.e. interstitial Ca-profiles, $\mathrm{CaCO}_{3}$-contents, and watercontents, suggest to us consistently that the depletion of interstitial $\mathrm{Ca}^{2+}$ directly reflects authigenic carbonate mineral formation.

\section{Mechanism of carbonate precipitation}

To simplify our consideration on the mechanism of carbonate mineral precipitation, we will only consider $\mathrm{Ca}^{2+}$ and $\mathrm{CO}_{3}{ }^{2-}$ as the main components of the precipitates although dolomite and magnesian calcites are common 


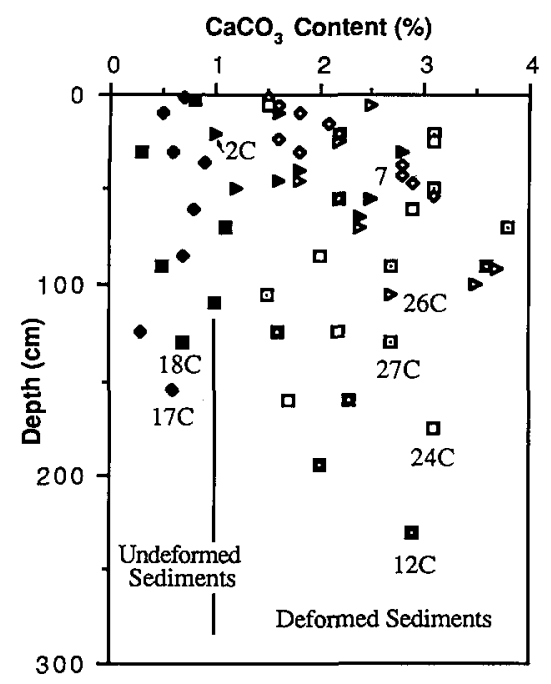

Fig.4. Downcore profiles of percent $\mathrm{CaCO}_{3}$ in sediments from different tectonic settings. $\mathrm{High} \mathrm{CaCO}_{3}$-content in deformed sediments and low $\mathrm{CaCO}_{3}$-content in undeformed sediments correspond, respectively, to an interstitial Cadecrease and a $\mathrm{Ca}$-increase.

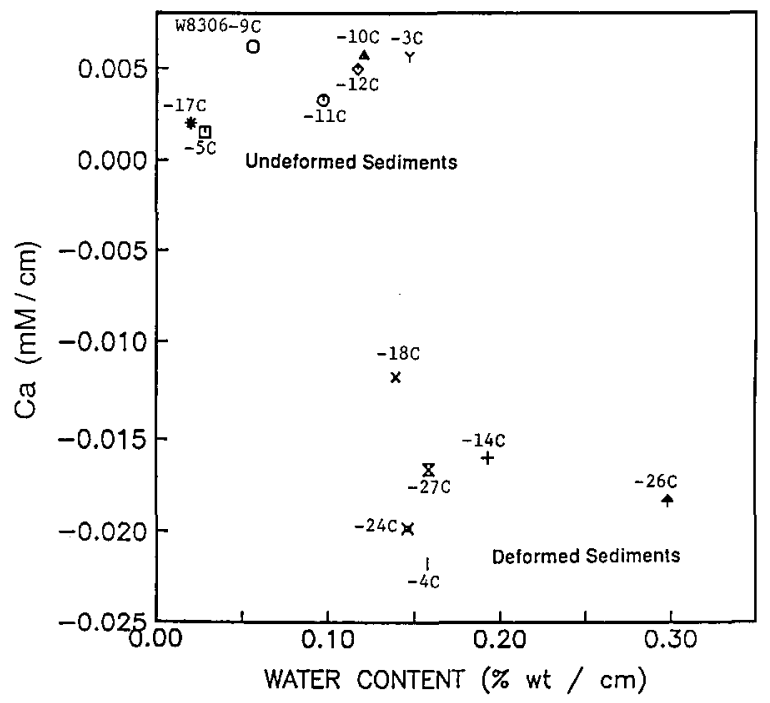

Fig.5. Water content- and interstitial Ca-gradients. Core stations where interstitial $\mathrm{Ca}$ decreases with depth show greater reduction in water content than stations with interstitial Ca-enrichment.

(Russell et al., 1967; Scamman, 1981; Ritger et al., 1987). In order to identify the mechanism of carbonate mineral precipitation, we have to address briefly the origin of the two main reactants. Calcium, ultimately of crustal origin, is transported into the accreted sediments by upward advecting fluids. The $\mathrm{CO}_{3}{ }^{2-}$. ion, which may be provided by oxidation of migrated methane, is equally brought to the near-surface depths by venting fluids. We propose that oxidation of the migrated methane and the decrease in carbonate solubility (or conversely an increase in calcium carbonate saturation) due to the release of excess pore pressure play an important role in the formation of carbonate mineral precipitates.

\section{Migration and oxidation of methane}

During biochemical degradation of organic matter in sediments, $\Sigma \mathrm{CO}_{2}$ is generated by aerobic oxidation near the sediment-water interface followed by anaerobic oxidation below, generally by sulfate reduction (Claypool, 1974; Berner, 1980). When sulfate is exhausted from the interstitial water, the process of biogenic methane formation takes place by $\mathrm{CO}_{2}$-reducing microbes, which utilize the pool of dissolved bicarbonate generated during sulfate reduction.

In the process of microbial methane formation the residual bicarbonate is progressively enriched in ${ }^{13} \mathrm{C}\left(\delta^{13} \mathrm{C}=-40\right.$ to $\left.+10 \%\right)$ and biogenic methane is depleted in ${ }^{13} \mathrm{C}$ $\left(\delta^{13} \mathrm{C}=-90\right.$ to $-70 \%$ ) (Claypool and Kvenvolden, 1983). An increase in the $\mathrm{pH}$ due to removal of $\mathrm{\Sigma CO}_{2}$ from pore water during biogenic methane production may cause precipitation of carbonate in anoxic sediments. The carbonate originated by this methanogenic process is thus enriched in ${ }^{13} \mathrm{C}$ as it is formed from ${ }^{13} \mathrm{C}$-enriched bicarbonate (Claypool and Kaplan, 1974). However, carbonates with anomalously light $\delta^{13} \mathrm{C}$ values $\left(\delta^{13} \mathrm{C}=-35\right.$ to $\left.-67 \%\right)$ in the deformed sediments (Schroeder et al., 1987; Ritger et al., 1987 ) indicate that they could not have originated from this diagenetic process. Instead oxidation of biogenic methane appears to be the only process by which the strongly ${ }^{13} \mathrm{C}$ depleted carbonate ions could have been derived. The methane must have been trans- 
ported toward the surface and be oxidized in order to precipitate carbonate in near-surface sediments. The oxidation process and generation of highly ${ }^{13} \mathrm{C}$-depleted bicarbonate ions in the Oregon underthrust pore fluids are documented by Suess and Whiticar (this issue).

A parcel of venting pore fluid, driven by positive excess pore pressure, continually adjusts to the total hydrostatic pressure on its path upward through the sediment column by releasing its excess pore pressure. In the case of methane saturation this release of pore pressure results in a corresponding decrease in the amount of methane dissolved in the pore fluid. Methane may thus escape through ebullition and accelerate transport from depth to the surface. As methane reaches the near-surface sediments, it is oxidized by oxygen or sulfateconsuming microbes, providing an abundant source of $\delta^{13} \mathrm{C}$-depleted carbonate ions $\left(\delta^{13} \mathrm{C}=-30\right.$ to $-70 \%$ ) (Claypool, 1974) from which anomalously $\delta^{13} \mathrm{C}$-depleted authigenic carbonate minerals are formed. Occurrence of pyrite in carbonates suggests that anaerobic oxidation of methane by sulfate reducing microbes is the more dominant process in the Oregon subduction zone than aerobic oxidation (Ritger et al., 1987).

Anomalously light carbonate minerals were also observed in Oregon continental shelf (DSDP Leg 18 site 176) at $22 \mathrm{~m}$ subsurface (Claypool, 1974) and slope (Russell et al., 1967) sediments. Migration of methane from depth to this horizon was proposed by Claypool (1974) to explain these $\delta^{13} \mathrm{C}$-depleted carbonates. Fluid advection from depth to present near-surface sediments was also proposed from the ${ }^{12} \mathrm{C}$ enriched dissolved $\Sigma \mathrm{CO}_{2}$ in shallow pore fluids of the accretionary complex (Suess and Whiticar, this issue). These authors predict that $30 \%$ of the dissolved $\Sigma \mathrm{CO}_{2}$ resulted from methane oxidation. These estimates are consistent with fluid-induced carbonate lithification in the deformed sediments.

\section{The effect of pressure on carbonate solubility}

In the case of fluid filled porous media, the effective stress is the weight of the overburden, which includes the weight of the water per unit area, minus the pore pressure (Rubey and Hubbert, 1959). Thus pore fluid venting occurs when the pore pressure exceeds the weight of the hydrostatic pressure and continues until the pore pressure equals the weight of the overlying water. This excess pore pressure is likely to be generated in subduction zones where compressional stress is exerted by converging plates (Von Huene, 1985). During upward migration of pore fluid this excess pore pressure must be released. The release may be one potential mechanism by which carbonate minerals precipitate in near-surface sediments of the deformed accretionary sediments, as the carbonate mineral solubility is proportional to pressure. The release of excess pore pressure in near-surface sediments is in turn proportional to the rate of pore fluid venting. The faster the pore fluids escape, the more likely carbonate minerals precipitate if precipitation is only governed by the effect of pressure on carbonate solubility.

The excess pore pressure gradient may be related to the rate of pore fluid venting by Darcy's law (Bear, 1972):

$u=K P / \eta z$ or $=k \mathrm{P} / n \rho g$

where $u$ is the rate of pore fluid flow, $K$ is the permeability of the porous medium, $P$ is the excess pore pressure over any subsurface depth, $z, k$ are the hydraulic conductivity, $\eta$ is the viscosity of pore fluid, $n$ is the porosity of sediments, $\rho$ is the density of pore fluid and $g$ is the gravitational acceleration. From Eq.(1) the venting rate and the excess pore pressure gradients are related by the expression:

$P(\mathrm{~atm}) / z(\mathrm{~m})=3.3 u\left(\mathrm{~m} \mathrm{y}^{-1}\right)$

if $k=7 \times 10^{-10} \mathrm{~m} \mathrm{~s}^{-1}, \quad n=0.7, \rho=1.05 \mathrm{~g} / \mathrm{cm}^{3}$, and $g=9.8 \mathrm{~m} / \mathrm{s}^{2}$ are fixed.

Suppose a parcel of pore fluid flows from a subsurface depth of $z$ to the sea floor at a water depth of $2.1 \mathrm{~km}$ (which is the approximate water depth of the vent site where authigenic carbonate chimneys and benthic organisms were found, Kulm et al., 1986), hydrostatic pressure at this water depth is approximately 
equivalent to $210 \mathrm{~atm}(10 \mathrm{~m}$ water column $\approx 1 \mathrm{~atm}$ ). Equation (2) predicts that for a venting rate of $10 \mathrm{my}^{-1}$, the total pressure at $6 \mathrm{~m}$ subsurface would have to be $408 \mathrm{~atm}$. This represents the sum of $198 \mathrm{~atm}$ from excess pore pressure plus $210 \mathrm{~atm}$ from hydrostatic pressure.

The $6 \mathrm{~m}$ thickness for the subsurface layer where precipitation might take place, is arbitrary. Based on porosity reduction, however, Scamman (1981) assumed that cementation would begin at shallow burial depth, probably within several meters of the sediment-water interface. $\mathrm{CaCO}_{3}$ precipitation below this subsurface depth is unlikely because methane oxidation, by which carbonate ions is provided for $\mathrm{CaCO}_{3}$ precipitation, would not occur below this depth due to the exhaustion of interstitial sulfate available for methane oxidation. If carbonate mineral precipitation was entirely controlled by thermodynamic equilibration of pure calcite, the amount of $\mathrm{CaCO}_{3}$ which will be precipitated at a venting rate of $10 \mathrm{my}^{-1}$ would be equivalent to the difference in the equilibrium Ca-concentrations between $408 \mathrm{~atm}$ and $210 \mathrm{~atm}$, i.e., between the sediment surface and $6 \mathrm{~m}$ subsurface below sea floor.

Details of the thermodynamic equilibrium model, quantifying $\mathrm{CaCO}_{3}$ precipitation by the release of pore pressure, are described in the Appendix. The result of this thermodynamic equilibrium model for $\mathrm{CaCO}_{3}$-precipitation shows the following linear relationship between $\% \mathrm{CaCO}_{3}$ and excess pore pressure over the $6 \mathrm{~m}$ subsurface interval (Fig.6);

$$
\log \left(\% \mathrm{CaCO}_{3}\right)=-4.6564+1.0262 \log (P)
$$

or

$$
=-4.6564+1.0262 \log (3.3 u z)
$$

This linear relationship indicates that the greater the excess pore pressure (i.e., faster venting rate) the greater the $\mathrm{CaCO}_{3}$-precipitation, because the difference in the equilibrium Ca-concentrations between the subsurface and the sediment surface will be enhanced by increasing pressure difference. The $6 \mathrm{~m}$-thickness is only for illustration and will be

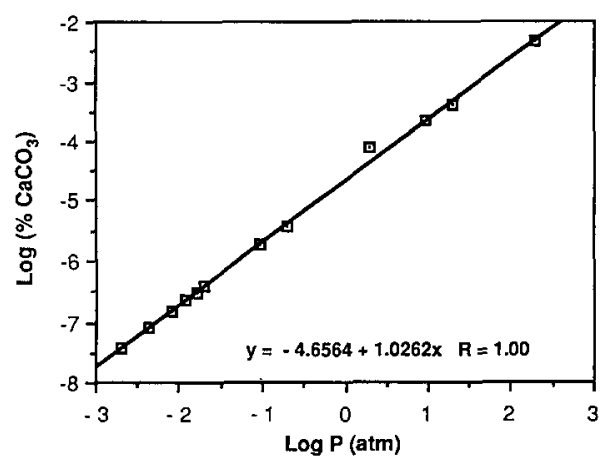

Fig.6. Theoretical relationship between the release of excess pore pressure and the amount of potential $\mathrm{CaCO}_{3}$ precipitation (in weight \%) responding to the pore pressure release. Thermodynamic equilibrium was assumed for pure calcite precipitation. The symbols $\square$ represent the relationship between excess pore pressure and precipitation of $\mathrm{CaCO}_{3}$ as predicted by equations developed in the Appendix. Wet bulk density and porosity fraction of sediment are assumed as $1.3 \mathrm{~g} / \mathrm{cm}^{3}$ and 0.7 , respectively.

extended later in this section to a more appropriate subsurface depth in order to establish a thermodynamic equilibrium model that best takes into account the effect of the release of excess pore pressure on $\mathrm{CaCO}_{3}$ precipitation.

The amounts of $\mathrm{CaCO}_{3}$ formed from fluid venting from only a 6 -m thick sediment layer are very small. Figure 6 shows that the amount of $\mathrm{CaCO}_{3}$ precipitated from the release of pore pressure can not account for the measured $\mathrm{CaCO}_{3}$ content in some of the sediments even at the extreme venting rate of $10 \mathrm{my}^{-1}$. This is due to setting the subsurface base at $6 \mathrm{~m}$ which implies that venting pore fluids originate from this depth. The disagreement between predicted and measured amounts of $\mathrm{CaCO}_{3}$ precipitation, therefore, suggests a need for extension of the subsurface interval from which the fluids are generated. The relation of Eq.(3) will still hold at any depth below the $6 \mathrm{~m}$ subsurface as the model assumes an exclusive thermodynamic control on carbonate precipitation in response to the release of excess pore pressure.

The thermodynamic equilibrium model for calcite precipitation in case of the extended depth below $6 \mathrm{~m}$ is illustrated in Fig.7. This 


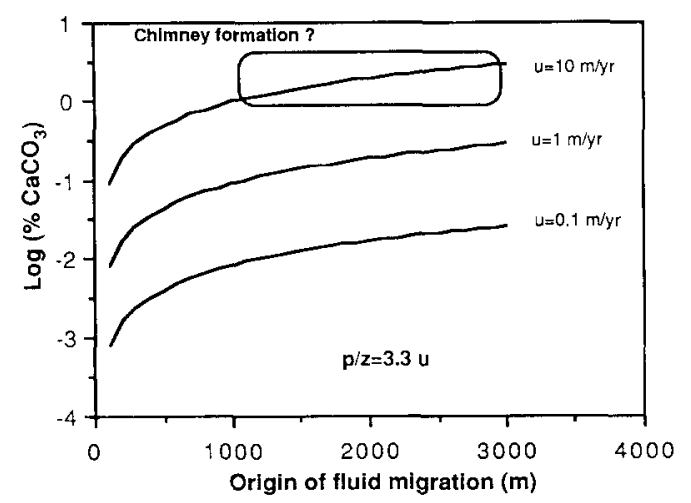

Fig. 7. Theoretical relationship between $\mathrm{CaCO}_{3}$-content (in weight $\%$ ) of lithified sediments and the proposed depths for the origin of pore fluids, at varying advection rates. Given this relationship predicts carbonate precipitation in low limits because of the restrictive assumption of the thermodynamic control on the precipitation, $\mathrm{CaCO}_{3}$. content of $1 \%$ may be assumed as significant and could be comparable to the formation of carbonate chimneys in real situation. The relationship then predicts that chimney formation is only likely when fluid venting rates are in the range of $10 \mathrm{~m} \mathrm{yr}^{-1}$ with the origin of fluid migration greater than $1 \mathrm{~km}$ subsurface.

diagram is obtained by plotting the two parameters in Eq.(3), $z$ and $\log \left(\% \mathrm{CaCO}_{3}\right)$, on $x$ - and $y$-axes. The relationship between these two parameters is illustrated with varying values of pore fluid advection, $u$. It shows that significant $\mathrm{CaCO}_{3}$ precipitation $(\gg 1 \%)$ is likely at venting rates and source depths of fluids at around $10 \mathrm{my}^{-1}$ and $1 \mathrm{~km}$, respectively. If one takes into account the restrictive assumption that carbonate precipitation is entirely controlled by equilibration of pure calcite in response to the release of excess pore pressure, then the conditions specified in Fig.7 are lower limits of carbonate mineral precipitation. It is interesting to note that only a fairly fast venting rate of $10 \mathrm{my}^{-1}$ and a source depth for pore fluids of $1 \mathrm{~km}$ may generate chimneys. Slower rates provide $\mathrm{CaCO}_{3}$ sufficient only for cementation or even less as in the disseminated rhombs of $\mathrm{CaCO}_{3}$ of the Oregon margin sediments (Ritger et al., 1987).

The interstitial calcium profile obtained from DSDP site $174 \mathrm{~A}$ in the Cascadia abyssal plain shows a Ca-minimum $(<10 \mathrm{mM})$ at subbottom depths of $50 \cdots 350 \mathrm{~m}$, but a drastic Ca- enrichment, much higher than normal seawater $\mathrm{Ca}^{2+}(\gg 10 \mathrm{mM})$, at depth greater than $350 \mathrm{~m}$ (Watermann et al., 1972; Claypool, 1974). Thus, venting of pore fluids from the deformation of these sediments must migrate vertically from at least a depth of $350 \mathrm{~m}$ and carry crustal $\mathrm{Ca}^{2+}$ upwards in order to precipitate carbonate in near-surface sediments.

The thermodynamic equilibrium model for calcite suggests that pressure control on carbonate solubility would be a significant mechanism for the formation of the carbonate chimney should the venting rate be in the range of $10 \mathrm{my}^{-1}$ or greater. A minimum flow rate of $277 \mathrm{ml} \mathrm{m} \mathrm{m}^{-2}$ day $^{-1}$ was directly measured above a vent site in the deformation front of the Oregon accretionary complex (Suess et al., 1987). This rate is equivalent to only $20-50 \mathrm{~cm} \mathrm{y}^{-1}$ of vertical migration depending on the porosity. On the other hand, a venting rate as high as $200 \mathrm{~cm} \mathrm{y}^{-1}$ was estimated from a systematic change in methane concentrations in timed water samples that were obtained by deploying a benthic chamber above the vent site (E. Suess, pers. observation).

Evidently, the high required flow rate of $10 \mathrm{my}^{-1}$ by the thermodynamic model is just barely approached in any of the measured flow rates. Considering the assumption of the model that carbonate precipitation be entirely controlled by solubility of pure calcite and the release of excess pore pressure associated with pore fluid venting, any closer agreement would be fortuitous. What is significant, however, is that both the measured and the model-derived flow rates are considerably faster than any reported venting rates in other accretionary complexes, which are on the order of $1 \mathrm{~cm} \mathrm{y}^{-1}$ at most (Boulegue et al., 1987; Reck, 1987).

Ritger et al. (1987) point out that normally undersaturated bottom waters, (with respect to calcite), bathe the entire Cascadia accretion. ary complex. Therefore, carbonate mineral precipitation requires supersaturation generated from local conditions within the sediment column and not at the sediment water interface. Calculations of the ion-concentration- 
product (ICP), $\left[\mathrm{Ca}^{2+}\right] \times\left[\mathrm{CO}_{3}{ }^{2-}\right]$, using $\mathrm{pH}$ and dissolved $\Sigma \mathrm{CO}_{2}$ data in pore waters of the area indicate supersaturation of the pore waters with respect to calcite (Fig.8).

However, pore waters not only from the deformed sediment but also from the undeformed abyssal plain sediment are supersaturated with respect to calcite (Fig.8). Nonetheless, the degree of supersaturation in the deformed sediments is significantly higher than in the undeformed abyssal plain sediments. Admitting a large margin of error accumulated in these calculations and analyses, this systematic difference in the degree of saturation may suggest undersaturation of the pore waters from the undeformed abyssal plain with respect to calcite. Another possibility is that the saturation in these pore fluids is controlled not by pure calcite but by a mixed carbonate mineral phase, whose solubility is higher than that of calcite.

Supersaturation with respect to calcite in

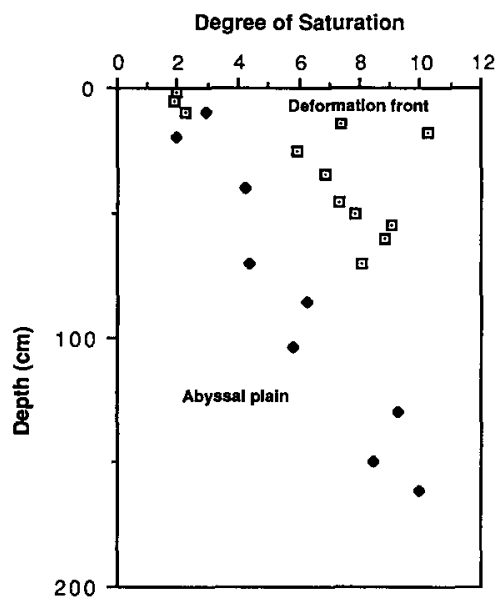

Fig.8. Degree of saturation of the pore waters from both the deformed and the undeformed abyssal plains with respect to calcite. Pore waters from both the deformed (8306-2C) and the undeformed (8306-3C) abyssal plains are strongly supersaturated with respect to calcite. However, the pore waters from the deformed abyssal plain are systematically more saturated than those from the undeformed abyssal plain. Skirrow's (1975) relations for concentrations of carbon species were used to calculate ICP, $\left[\mathrm{Ca}^{2+}\right] \times$ $\left[\mathrm{CO}_{3}{ }^{2-}\right]$, of pore fluids. To finally obtain the degree of saturation the calculated ICPs were divided by $K_{s p}$ of $\mathrm{CaCO}_{3}$ at $0^{\circ} \mathrm{C}$ and $1 \mathrm{~atm}$, which were the approximate conditions during pore water sampling from squeezing. sediments devoid of calcium carbonate is quite common. An apparent increase in $\mathrm{CaCO}_{3}$ saturation was also reported at depths of all sediments from the North American continental margin off Nova Scotia and from the central Pacific (Sayles, 1987). This author concluded that the ICP increases cannot be adequately described by a single thermodynamic constant. Nevertheless, we think that the relative difference in calcite saturation between pore waters from deformed and undeformed sediments is significant and is another indication for the enhanced calcium carbonate precipitation in sediments affected by fluid venting.

\section{Evidence for venting from interstitial water}

In addition to the first direct measurement of pore fluid venting rates at the vent site in the Cascadia accretionary complex (Suess et al., 1987), downcore concentration profiles of chemical species, such as $\mathrm{Ca}^{2+}$ and $\mathrm{NH}_{4}{ }^{+}$can be used to ascertain vertical flow rates (Maris et al., 1984 and Bender et al., 1985). Rates of pore fluid venting were determined by applying one-dimensional diffusion-advection-reaction models to the downcore concentration profiles of interstitial $\mathrm{Ca}^{2+}$ and $\mathrm{NH}_{4}{ }^{+}$obtained from selected coring sites across the Cascadia accretionary complex. These stations are: $8408-4$ from the abyssal plain of the Oregon underthrust area; 8408-7, 8306-24C, and 8306$26 \mathrm{C}$ from the flank of the seaward deformation ridge (also of the Oregon underthrust area), and 8306-2C from the top of the sea mount on the abyssal plain off Washington.

The model equation applied to interstitial $\mathrm{Ca}^{2+}$ profiles may be written as

$D d^{2} C / d z^{2}-u d C / d z-k C=0$

where $D$ is the diffusion coefficient of $\mathrm{Ca}^{2+}, C$ is the concentration of interstitial $\mathrm{Ca}^{2+}, z$ is the vertical depth positive downward, $u$ is the advection rate of pore fluid, and $k$ is the coefficient of Ca-precipitation. The coordinate axis $z$ is positive downward originating at the 
sediment-water interface. The solution of Eq.(4) may be written as

$C(z)=C_{1} \exp \left(\lambda_{1} z\right)+C_{2} \exp \left(\lambda_{2} z\right)$

where,

$\lambda=\frac{u \pm \sqrt{u^{2}-4 k D}}{2 D}$

$C(z=0)=C_{1}+C_{2}$, and

$C(z=h)=C_{1} \exp \left(\lambda_{1} h\right)+C_{2} \exp \left(\lambda_{2} h\right)$.

$C(z=0)$ and $C(z=h)$ are known from the measured interstitial Ca concentrations and $D$ is assumed as $3 \times 10^{-6} \mathrm{~cm}^{2} \mathrm{~s}^{-1}$ (Lerman, 1977). The only unknown terms in Eq.(5) are $u$ and $k$. The linear concentration profile at station 8408-4 (abyssal plain) was assumed to indicate that the Ca-distribution is exclusively controlled by diffusion and reaction. At this station, therefore, the $u$-term was removed and subsequent curve fitting of Eq.(5) to the measured $\mathrm{Ca}^{2+}$ profile gave a value for $k$ (the coefficient of Ca-precipitation). This $k$ value was used in the other stations to determine $u$ by fitting Eq.(5) to the measured Ca-profiles at those stations.

Advection rates of pore fluids derived in this manner from the Ca-modeling range from $1 \mathrm{~cm}$ $\mathrm{y}^{-1}$ to $6 \mathrm{~cm} \mathrm{y}^{-1}$ upward, but are mostly of the magnitude around $1 \mathrm{~cm} \mathrm{y}^{-1}$ (Table II and Fig.9). Station 8306-2C, however, the site of the sea mount on the Washington abyssal plain shows the fastest advection rate with $28 \mathrm{~cm}$ $\mathrm{y}^{-1}$. In order to obtain the best curve fit a twolayer model was applied to the Ca-profile at this sea mount station. This sea mount is considered to be a mud volcano (L. D. Kulm, pers. comm.) which would readily explain the high advection rate.

Profiles of the measured interstitial $\mathrm{NH}_{4}{ }^{+}$

TABLE II

Input parameters used for diffusion-advection-reaction modelling of $\mathrm{Ca}$ - and $\mathrm{NH}_{4}$-distributions; comparison of calculated advection rates

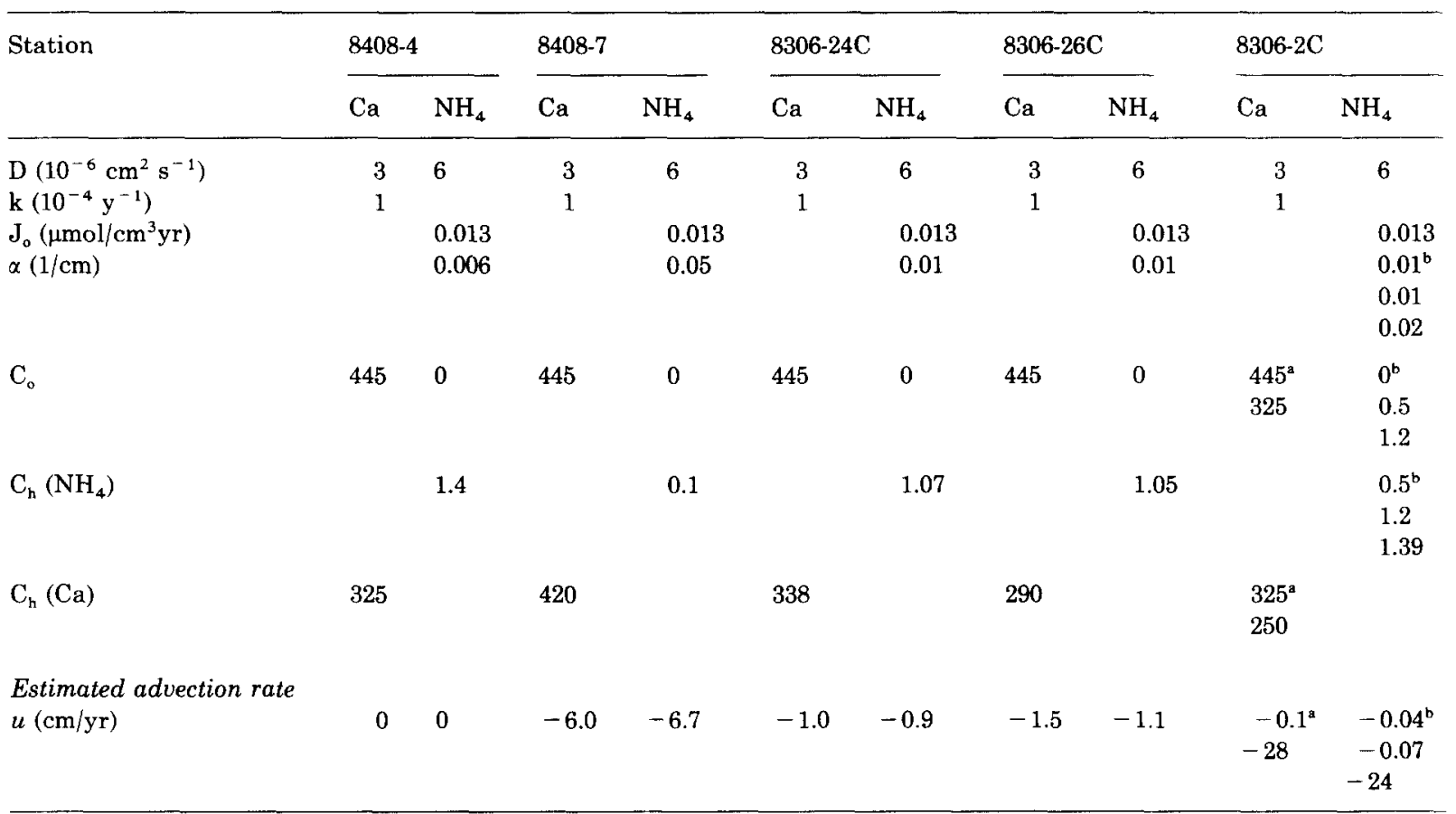

aTwo-layer model parameters for $\mathrm{Ca}$.

'Three-layer model parameters for $\mathrm{NH}_{4}$. 

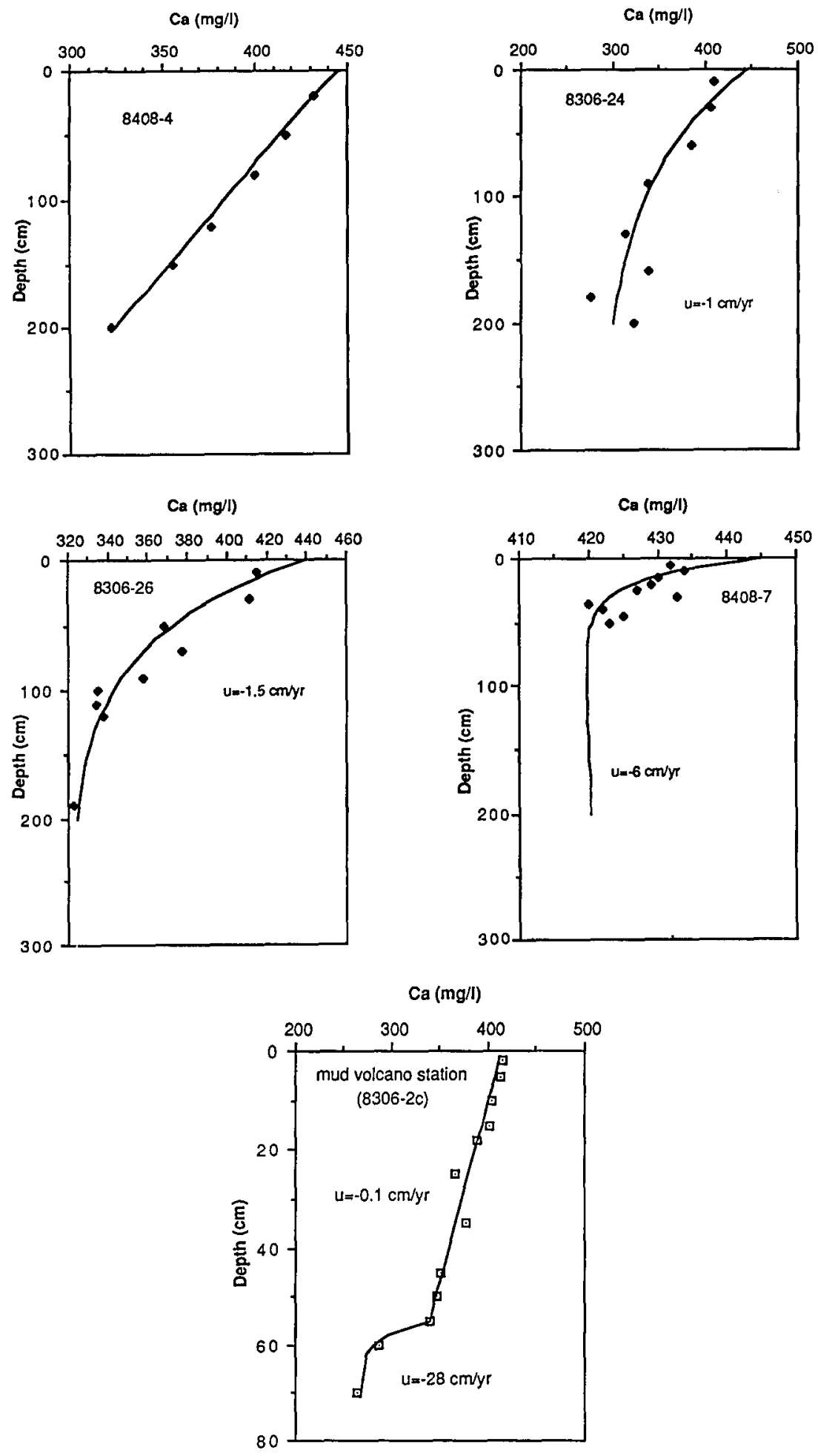

Fig.9. Application of a diffusion-advection-reaction model to interstitial Ca-profiles. Pore water advection rate $(u)$ was obtained by visual curve fitting of the model equation to the measured Ca-concentrations. Two-layer models were applied to the Ca-profile at the core station 8306-2C (sea mount) to obtain the best fit. Values of the model parameters used in the curve fitting are listed in Table II. 
may be described by another version of diffusion-advection-reaction model, which takes the following expression:

$D d^{2} C / d z^{2}-u d C / d z+J_{0} \exp (-\alpha z)=0$

where $J_{0}$ is the $\mathrm{NH}_{4}$-production rate at the sediment-water interface and $\alpha$ is the attenuation coefficient for concentration profile. The solution of Eq.(6) may be written as

$$
\begin{aligned}
& C(z)=C_{3}+C_{4} \exp (z u / D)-J_{0} \exp (-\alpha z) / \\
& \quad\left(D \alpha^{2}+u \alpha\right)
\end{aligned}
$$

where, $C(z=0)=C_{3}+C_{4}-J_{0} /\left(D \alpha^{2}+u \alpha\right)$ and $C(z=h)=C_{3}+C_{4} \exp (h u / D)-J_{0} \exp (-\alpha h) /$ $\left(D \alpha^{2}+u \alpha\right)$

$C(z=0)$ and $C(z=h)$ are known from the measured $\mathrm{NH}_{4}{ }^{+}$concentrations and $D$ is assumed as $6 \times 10^{-6} \mathrm{~cm}^{2} \mathrm{~s}^{-1}$ (Lerman, 1977). There are three unknown terms in Eq.(7); the attenuation coefficient $(\alpha)$, the production rate of $\mathrm{NH}_{4}{ }^{+}$at the surface $\left(J_{0}\right)$ and the advection rate $(u)$. At the station 8408-4 where the advection rate is assumed to be zero (based on the $\mathrm{Ca}^{2+}$ profile), only $J_{0}$ and $\alpha$ need to be defined. Assuming values of $\alpha$ in the range of $0.001-0.01$, the production rate $\left(J_{0}\right)$ can subsequently be constrained at the station 8408-4. With these constraints on $J_{0}$ and $\alpha$ the advection rate, $u$, for each station was determined by a curve fitting to the measured $\mathrm{NH}_{4}{ }^{+}$.

Advection rates derived from the $\mathrm{NH}_{4}$ modeling range from 1 to $7 \mathrm{~cm} \mathrm{y}^{-1}$ (Table II and Fig.10). The rate for the deeper portion of the sea mount station is $24 \mathrm{~cm} \mathrm{y}^{-1}$. These rates are consistent with the range obtained from Ca-modeling. All model-derived advection rates are compared in Table II. Reduced advection rates in the upper two layers of the sea mount station (Figs.9 and 10) appear to be due to the bottom water penetration which would obliterate advection signatures of the pore water chemistry.

All of the model-derived advection rates are 20-200 times slower than the rate measured right over the vent site. Considering that interstitial $\mathrm{Ca}$ - and $\mathrm{NH}_{4}$-data of all the core stations are from non-vent areas, yet from within the deformed accretionary complex, however, these model-derived advection rates appear to be reasonable. The great difference in magnitude of advection rates between a vent site and non-vent sites of the accretionary complex suggests that pore fluid expulsion is confined to small areas while pervasive upward migration of pore fluid occurs in most of the complex at much reduced rates. This confined pore fluid venting was also suggested during a numerical simulation of the thermal structure within the underthrust portion of the Oregon accretionary complex (Han, 1987).

\section{Implications}

\section{Global Ca-flux}

The composition of seawater is remarkably constant and has barely changed during the last 200 m.y. (Holland, 1972). There must be buffering mechanisms which maintain the ocean at steady-state composition, otherwise the ocean would turn into a highly alkaline lake by continuous input of river water. Though it is known that the steady-state seawater composition is controlled by mass fluxes between major chemical reservoirs on the Earth's surface that interact with the ocean: atmosphere, sediments, and continents (river input carrying weathering products), imbalances in mass fluxes among major chemical reservoirs still exist for some elements.

Fortunately a great improvement in explaining the steady-state seawater composition has been achieved by the discoveries of hydrothermal hot springs in mid-ocean ridges. It is now recognized that hydrothermal interaction between seawater and basalt of which the upper part of the igneous oceanic basement consists is a potential source and sink for various ions in seawater and thus a major process in buffering the seawater composition (Edmond et al., 1979; Hart and Staudigel, 1982; Thompson, 1983; Von Damm et al., 1985). Major imbalances in previous global geochemical budgets for elements, such as magnesium, were considerably reduced by inclusion of hydro- 

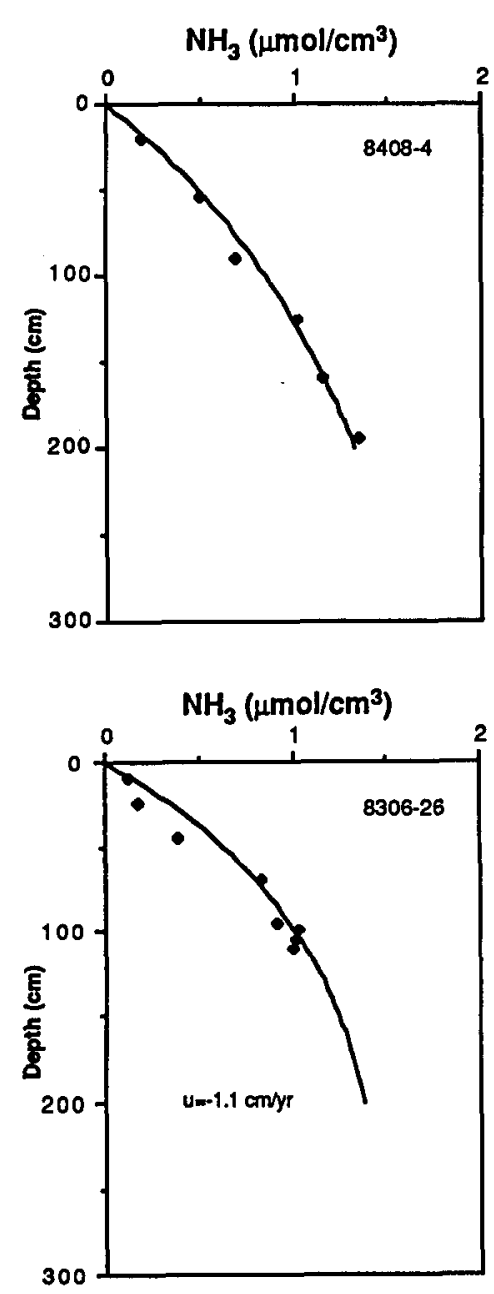

$\mathrm{NH}_{3}\left(\mu \mathrm{mol} / \mathrm{cm}^{3}\right)$
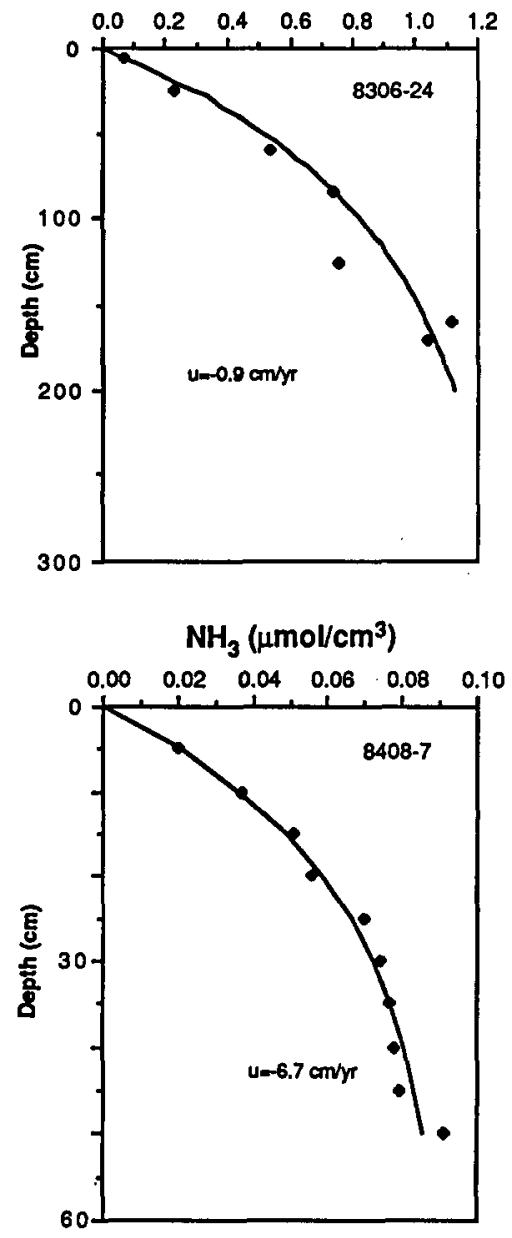

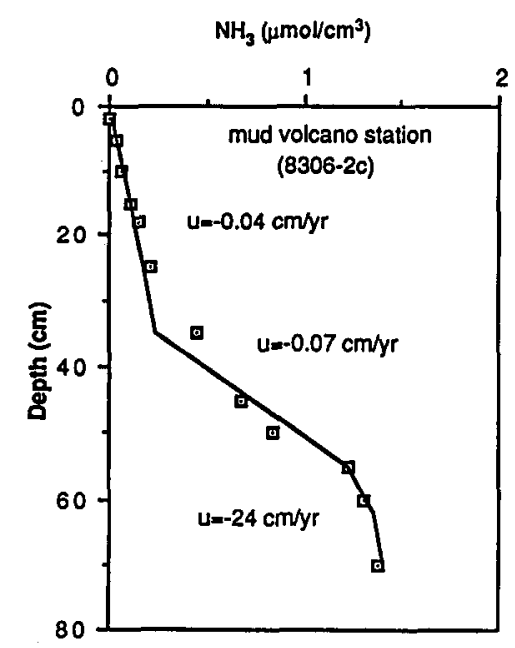

Fig.10. Application of a diffusion-advection-reaction model to interstitial $\mathrm{NH}_{\mathbf{4}}$-profiles. Pore water advection rates obtained from $\mathrm{NH}_{4}$-modeling are comparable to those from Ca-modeling. Three-layer models were applied to the $\mathrm{NH}_{4}$-profile at the core station 8306-2C (sea mount) to obtain the best fit. Values of the model parameters used in the curve fitting are listed in Table II. 
thermal flux estimates to the extent that no other mechanism needed to be invoked (Drever, 1974; Von Damm et al., 1985). Therefore, much effort has since been focused on refining the fluxes of elements exchanging between the ocean and the oceanic basement (Thompson, 1983).

In this paper we deal only with one aspect of the global geochemical budget for calcium; i.e. the role of pore fluid venting along accretionary complexes in affecting the steady-state Ca-composition of seawater. To maintain the Ca-composition in steady-state, the major geochemical reservoirs of $\mathrm{Ca}^{2+}$ and the Ca-fluxes between those reservoirs must be identified. For a steady-state Ca-model we consider five major reservoirs: ocean, continent, sediment, oceanic basement, and mantle (Fig.11). Since a certain portion of sediment is subducted and lost to the mantle, the mantle should be included as a geochemical reservoir.

The Ca-flux from the continents to the oceans (Fig.11; $A \rightarrow B$ ) is characterized by river input carrying weathering products. The $\mathrm{Ca}$ flux from the oceans to the sediments (Fig.11; $B \rightarrow C$ ) is represented by calcareous ooze and Ca-uptake by alumino-silicates. Garrels and

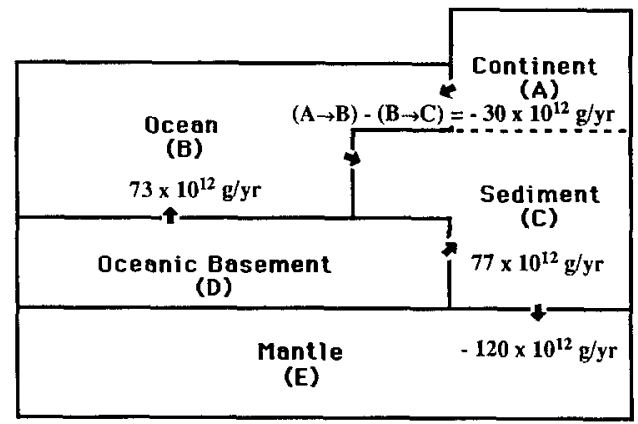

Fig.11. A global model for the $\mathrm{Ca}^{2+}$ mass balance. The arrows indicate $\mathrm{Ca}$-fluxes between the major geochemical reservoirs: continent $(A)$, ocean $(B)$, sediment $(C)$, oceanic basement $(D)$, and mantle $(E)$. The total Ca-deficit, $-150 \times 10^{12} \mathrm{~g} \mathrm{y}^{-1}$ is balanced by the Ca-inputs from the hydrothermal Ca-flux $(D \rightarrow B), 73 \times 10^{12} \mathrm{~g} \mathrm{y}^{-1}$, and from the proposed Ca-flux $(D \rightarrow C), 77 \times 10^{12} \mathrm{~g} \mathrm{y}^{-1}$, which carries crustal $\mathrm{Ca}^{2+}$ directly to the sediment record and is characterized by carbonate mineral precipitation from pore fluid venting in accretionary complexes of the world's subduction zones.
Mackenzie (1971) recognized that sedimentary rocks contain such a large excess of $\mathrm{Ca}^{2+}$ that the river input of $\mathrm{Ca}^{2+}$ from the weathering of average igneous rock can not account for it. Wolery and Sleep (1976) suggested that a Cainput of at least $30 \times 10^{12} \mathrm{~g} \mathrm{y}^{-1}$ is needed to balance this Ca-deficit. They also suggested that Ca-containing sediments are subducted and lost to the mantle (Fig.11;C $\rightarrow E$ ) at a maximum rate of $120 \times 10^{12} \mathrm{~g} \mathrm{y}^{-1}$. Therefore, an even larger total Ca-input of $150 \times 10^{12} \mathrm{~g} \mathrm{y}^{-1}$ is needed to balance the sedimentary Cabudget.

Hydrothermal input (Fig.11; $D \rightarrow B$ ) is known to be a significant source for this additionally needed $\mathrm{Ca}^{2+}$. The most recent estimate for hydrothermal Ca-input, which includes fluxes from all types of seawater-basalt reaction, is given as $73 \times 10^{12} \mathrm{~g} \mathrm{y}^{-1}$ (Thompson, 1983). Accepting this recent estimate, the input still falls short of the total amount of $\mathrm{Ca}^{2+}$ required by about $77 \times 10^{12} \mathrm{~g} \mathrm{y}^{-1}\left(150 \times 10^{12}-73 \times 10^{12} \mathrm{~g}\right.$ $\left.\mathrm{y}^{-1}\right)$. This deficit may indicate that the maximum Ca-flux to the mantle by sediment subduction is grossly overestimated. If this were the case, the hydrothermal Ca-input $\left(73 \times 10^{12} \mathrm{~g}\right.$ $\mathrm{y}^{-1}$ ) would be sufficient if the Ca-flux to the mantle were reduced to $43 \times 10^{12} \mathrm{~g} \mathrm{y}^{-1}$. This is where the discussion on the global Ca-budget stands today. At present there is no way to independently verify the rate of Ca-loss to the mantle by subduction, nor to update the hydrothermal $\mathrm{Ca}$-input. The most recent estimate of hydrothermal Ca-input appears to be a reliable and well-refined value.

However, another way of reducing the $\mathrm{Ca}$ deficit is by taking into account all $\mathrm{Ca}^{2+}$ removed by carbonate mineral precipitation from pore fluid venting in accretionary complexes. This pathway directly supplies crustal $\mathrm{Ca}^{2+}$ to the sediment record without passing through the intermediate ocean reservoir (Fig.11; $D \rightarrow C$ ). Our hypothesis of the crustal Ca-flux in subduction zones becomes important as the Ca-flux to the mantle by sediment subduction approaches a maximum. The recent estimate for the hydrothermal Ca-input, $73 \times 10^{12} \mathrm{~g} \mathrm{y}^{-1}$, is still insufficient to maintain 
steady-state if $\mathrm{Ca}^{2+}$ is subducted at the maximum rate. Accordingly, as much as $77 \times 10^{12} \mathrm{~g}$ $\mathrm{y}^{-1}\left(150 \times 10^{12}-73 \times 10^{12}\right)$, could potentially be supplied by direct transport from the oceanic basement to the sediment reservoir via carbonate mineral precipitation associated with pore fluid venting in subduction zones (Fig.11; $D \rightarrow C$ ).

Carbonate mineral precipitation, coupled with depletion in interstitial $\mathrm{Ca}^{2+}$ in the world's subduction zones, supports such a pathway for Ca-flux. Authigenic carbonates in the near-surface sediments of the Nankai Trough, which are accompanied by the depletion of interstitial $\mathrm{Ca}^{2+}$, is another example, besides the Cascadia subduction zone, for the potentially world-wide effect of convergenceinduced Ca-precipitation (Kawahata and Fujioka, 1986; Stein and Smith, 1986). Calcium carbonate lithification and extensive dolomite formation along the Peru continental margin also support our hypothesis (Kulm et al., 1988). On a world-wide basis interstitial $\mathrm{Ca}^{2+}$ is enriched at depth, as seen in numerous DSDPdata and ODP-data, by leaching from the basaltic basement and subsequent diffusive transport to overlying sediments (McDuff and Gieskes, 1976; McDuff, 1981). However, when pore fluid venting is initiated by the excess pore pressure in subduction zones, this crustal $\mathrm{Ca}^{2+}$ is transported upward and is removed from the fluids to form authigenic carbonates.

This newly defined Ca-flux, potentially as large as $77 \times 10^{12} \mathrm{~g} \mathrm{y}^{-1}$, in subduction zones is about as much as the hydrothermal Ca-flux and less by a factor of seven than the river Ca-flux. The significance of this Ca-flux associated with pore fluid venting entirely depends on the accuracy of the Ca-flux estimate to the mantle by subduction. As discussed above, if the Caflux to the mantle is reduced to $43 \times 10^{12} \mathrm{~g} \mathrm{y}^{-1}$, the crustal Ca-flux identified here would be superfluous. However, this seems to contradict the evidence in the form of carbonate mineral precipitates associated with pore fluid venting along subduction zones. Thus the lower limit for the Ca-flux to the mantle must be larger than $43 \times 10^{12} \mathrm{~g} \mathrm{y}^{-1}$. Only a further study on the world's accretionary complexes would yield an independent estimate of the Ca-flux associated with pore fluid venting in order to constrain the Ca-flux to the mantle.

\section{Summary}

Downcore depletions of interstitial $\mathrm{Ca}^{2+}$ and reduction in porosity with the occurrence of carbonate precipitates over the Cascadia accretionary complex suggests that interstitial $\mathrm{Ca}^{2+}$ is removed by a convergence-induced calcium carbonate precipitation mechanism. The release of excess pore pressure, which drives the pore fluids, and the injection of methane-derived $\Sigma \mathrm{CO}_{2}$ during venting, are two processes by which calcium carbonate precipitation may be induced. Thermodynamic consideration on calcite solubility associated with the release of excess pore pressure suggests that the formation of carbonate chimneys requires the venting rate to be at least $10 \mathrm{~m} \mathrm{y}^{-1}$ with a source depth of fluids of at least $1 \mathrm{~km}$.

A global flux of $\mathrm{Ca}^{2+}$ that is carried from the ocean basement directly to the accreted sediments and removed by carbonate mineral precipitation associated with pore fluid venting in the world's subduction zones may be as much as the hydrothermal Ca-input. Such an optimistic estimate is only realistic if the Caflux to the mantle by sediment subduction is as large as $120 \times 10^{12} \mathrm{~g} \mathrm{y}^{-1}$ or does not drop below $43 \times 10^{12} \mathrm{~g} \mathrm{y}^{-1}$. The Ca-pathway suggested here, which was not previously considered in the global element budgets, implies that pore fluid venting in subduction zones may also be important in the budgets of other elements.

\section{Acknowledgement}

The work was made possible by the NSF grants OCE-8215147 and OCE-8609789 (Principal Investigators: L. D. Kulm and E. Suess, Oregon State University). We thank the crew and master of the $R / V$ Wecoma and $R / V$ Atlantis-II for their expert support in coring operations during cruises in 1983 and 1984 to the continental margin off Oregon and Wash- 
ington. We thank M. von Breymann, C. A. Ungerer, P. Kalk, and A. Harrison for their valuable assistance during the shipboard and subsequent shore-based analytical work. Additional financial support was provided by a grant from the OSU Foundation.

\section{Appendix}

Calculation procedure for $\mathrm{CaCO}_{3}$ precipitation

If carbonate precipitation is assumed to be controlled by thermodynamic equilibrium of calcite with dissolved interstitial $\mathrm{Ca}^{2+}$, then precipitation of carbonate would depend only on pressure, temperature, $p \mathrm{CO}_{2}$, and the ionic strength of the pore fluids. Under this assumption we have estimated the amount of calcite precipitated as a function of the release of excess pore pressure in the process of pore fluid venting. Since the carbonate precipitation was observed in near-surface sediments, the effect of temperature on calcite solubility is ignored as the temperature gradient would be small and in the range of 1 to $2^{\circ} \mathrm{C}$, at most. Thermodynamic equilibrium between calcite and pore fluid requires the following reactions to be considered:

$$
\begin{aligned}
& \mathrm{CO}_{2}(\mathrm{~g})=\mathrm{CO}_{2}(\mathrm{aq}) \quad a \mathrm{CO}_{2}{ }^{*}=\alpha p \mathrm{CO}_{2} \\
& \mathrm{CO}_{2}{ }^{*}+\mathrm{H}_{2} \mathrm{O}=\mathrm{H}^{+}+\mathrm{HCO}_{3}{ }^{-} \\
& a \mathrm{H}^{+} a \mathrm{HCO}_{3}{ }^{-}=K_{1} a \mathrm{CO}_{2}{ }^{*} \\
& \mathrm{HCO}_{3}{ }^{-}=\mathrm{H}^{+}+\mathrm{CO}_{3}{ }^{2-} \\
& \quad a \mathrm{H}^{+} a \mathrm{CO}_{3}{ }^{2-}=K_{2} a \mathrm{HCO}_{3}{ }^{-} \\
& \mathrm{CaCO}_{3}=\mathrm{Ca}^{2+}+\mathrm{CO}_{3}{ }^{2-} \\
& \quad a \mathrm{Ca}^{2+} a \mathrm{CO}_{3}{ }^{2-}=K_{\mathrm{s}} \\
& \mathrm{H}_{2} \mathrm{O}=\mathrm{H}^{+}+\mathrm{OH}^{-} \quad a \mathrm{H}^{+} a \mathrm{OH}^{-}=10^{-14} \\
& 2 a \mathrm{Ca}^{2+}+\mathrm{aH}^{+}=a \mathrm{HCO}_{3}{ }^{-}+2 a \mathrm{CO}_{3}{ }^{2-}+a \mathrm{OH} \\
& \Delta \mathrm{Ca}^{2+}=\Delta \mathrm{HCO}_{3}{ }^{-}+\Delta \mathrm{CO}_{3}{ }^{2-}+\Delta \mathrm{CO}_{2}{ }^{*}
\end{aligned}
$$

According to Plath et al. (1980), calcite solubility may be written as

$$
\begin{aligned}
& \ln \left(K_{s p} / K_{s p=1 \text { at }}\right)=0.07132 \\
& \quad+0.0080412 P-2.2544 \times 10^{-5} P T
\end{aligned}
$$

where the subscript $p$ denotes pressure dependent calcite solubility $\left(K_{s}\right)$. From Pytkowicz (1982) $K_{s p=1 \text { at }}$ is given as

$$
\begin{aligned}
& -\log \left(K_{s}\right)_{p \leqslant=1 \text { at }}=6.5795-3.7159 \\
& \quad \times 10^{-5} T S+0.091056 T / S-22.10 / S
\end{aligned}
$$

Eq.I-8 was recommended for the temperature range of $0-25^{\circ} \mathrm{C}$, salinity $32-35 \%$, and pressure 1-1000 at by Pytkowicz (1982). Equation I-8 was used, with Eq.I-9, to generate pressure dependent calcite solubility, $K_{s p}$, as these conditions for temperature, salinity, and pressure are applicable to the accretionary complex of the Oregon/Washington subduction zone. Salinity and temperature were assumed to be $35 \%$ and $0^{\circ} \mathrm{C}$ respectively.

Henry's law constant, $\alpha$, in seawater is available from Weiss (1974). The first and the second apparent dissociation constants, $K_{1}$ and $K_{2}$, are obtained from the extrapolation of the data set of Pytkowicz (1982), which are based on the data of Mehrbach et al. (1973) and Plath et al. (1980):

$$
\begin{aligned}
& 10^{7} K_{1}=0.0131 P+4.8130 \\
& (R-S Q=0.988) \text { at } 0^{\circ} \mathrm{C} \text { and } 35 \% \\
& 10^{10} K_{2}=0.0040 P+3.1510 \\
& (R-S Q=0.994) \text { at } 0^{\circ} \mathrm{C} \text { and } 35 \%
\end{aligned}
$$

Equation I-6 is for electroneutrality. Equation I-7 expresses that the change in $\mathrm{Ca}^{2+}$ is balanced by the change in carbon species. Equation I-7 can be rewritten as

$a \mathrm{Ca}^{2+}{ }_{p}-a \mathrm{Ca}^{2+}{ }_{p=\mathrm{ref}}=a \mathrm{TCO}_{2 p}-a \mathrm{TCO}_{2 p \approx \mathrm{ref}}$

where the subscript $p$ denotes pressure dependent concentration: for example, $a \mathrm{Ca}^{2+}{ }_{p=\text { ref }}$ and $a \mathrm{Ca}^{2+}$ are respectively equilibrium concentration of $\mathrm{Ca}^{2+}$ at a reference position and at a subsurface base.

We need to set a reference position and obtain equilibrium concentrations of $\mathrm{Ca}^{2+}$ and carbon species at the reference position as we will calculate the amount of $\mathrm{Ca}^{2+}$ precipitated from the difference in equilibrium concentrations of $\mathrm{Ca}^{2+}$ between $2.1 \mathrm{~km}$ sea floor and a base at subsurface. The reference position would be either on the sea floor or at the subsurface base. The base was assumed at $6 \mathrm{~m}$ subsurface. The reference position may be set at the sea floor of the proposed vent site, where the authigenic carbonate chimney and benthic 
community were found at $2.1 \mathrm{~km}$ water depth. In order to calculate in-situ equilibrium concentrations of $\mathrm{CO}_{2}{ }^{*}, \mathrm{HCO}_{3}{ }^{-}, \mathrm{CO}_{3}{ }^{2-}, p \mathrm{CO}_{2}$, and $\mathrm{Ca}^{2+}$ at the reference position of $2.1 \mathrm{~km}$ sea floor, however, the knowledge of $\mathrm{CO}_{2}$ solubility coefficient and $p \mathrm{CO}_{2}$ at the high pressure of $210 \mathrm{~atm}$ is essential. Limited information on these two parameters to the temperature range in $12-40^{\circ} \mathrm{C}$ at high pressure (Wiebe and Gaddy, 1940; Weiss, 1974) forced us to reset the reference position at a level of $0^{\circ} \mathrm{C}$ and $1 \mathrm{~atm}$. Our strategy is then to estimate the change in $\mathrm{Ca}^{2+}$ between the levels of $p=210 \mathrm{~atm}$ and $p=1 \mathrm{~atm}$ as well as the change in $\mathrm{Ca}^{2+}$ between the levels of pressure $(p>210 \mathrm{~atm})$ at the subsurface, and $p=1 \mathrm{~atm}$. Resulting differences between those two $\mathrm{Ca}^{2+}$ changes would finally be an amount of $\mathrm{Ca}^{2+}$ precipitated as calcite.

Substitution of the equilibrium concentrations, $\mathrm{CO}_{2}{ }^{*}, \mathrm{HCO}_{3}{ }^{-}$, and $\mathrm{CO}_{3}{ }^{2-}$ at $0^{\circ} \mathrm{C}$ and 1 atm, to Eq.(I-7) would reshape the seven equations in terms of seven unknown parameters. The system of equations was arranged to have an equation only in terms of $a \mathrm{H}^{+}$, and $a \mathrm{H}^{+}$in this equation was solved by the Newton iteration method. With the $a \mathrm{H}^{+}$value solved, the rest of the unknowns were solved sequentially. The entire solution process was repeated with varying excess pore pressure at the $6 \mathrm{~m}$ subsurface. The amount of $\mathrm{Ca}^{2+}$ precipitated was finally converted to $\% \mathrm{CaCO}_{3}$ content in the sediment;

$$
\% \mathrm{CaCO}_{3}=\left[\begin{array}{c}
\begin{array}{c}
\text { No. moles of Ca precip. } \times \\
100 \mathrm{~g} \mathrm{CaCO}_{3} \times \text { porosity }(n)
\end{array} \\
\begin{array}{c}
\text { Wet bulk density }\left(\mathrm{g} / \mathrm{cm}^{3}\right) \\
\times 1000\left(\mathrm{~cm}^{3}\right)
\end{array} \\
\times 100\left(\mathrm{~cm}^{3}\right)
\end{array}\right]
$$

\section{References}

Bear, J., 1972. Dynamics of Fluids in Porous Media. Elsevier, New York, N.Y., 674 pp.

Bender, M. L., Hudson, A., Graham, D. W., Barnes, R. O., Leinen, M. and Kahn, D., 1985. Diagenesis and convection reflected in pore water chemistry on the western flank of the East Pacific Rise, 20 degree south. Earth Planet. Sci. Lett., 76: 71-83.

Berner, R. A., 1980. Early Diagenesis: A Theoretical
Approach. Princeton Univ. Press., Princeton, N.J., $237 \mathrm{pp}$.

Boulegue, J., liyama, J. T., Charlou, J. L. and Jedwab, J., 1987. Nankai Trough, Japan Trench and Kuril Trench: Geochemistry of fluids sampled by submersible "Nautile". Earth Planet Sci. Lett., 83: 363-375.

Cadet, J. P., Kobayashi, K., Lallemand, S., Jolivet, L., Aubouin, J., Boulegue, J., Dubois, J., Hotta, H., Ishii, T., Konishi, K., Niitsuma, N. and Shimamura, H., 1987. Deep scientific dives in the Japan and Kuril trenches. Earth Planet. Sci. Lett., 83: 313-328.

Carson, B. and Berglund, P. L., 1986. Sediment dewatering associated with subduction-accretion: Experimental results. In: J. C. Moore (Editor), Structural Fabrics in DSDP Cores from Forearcs. Geol. Soc. Am. Mem., 166: 135-150.

Carson, B., Jennwei, Y., Meyers Jr., P. B. and Barnard, W. D., 1974. Initial deep-sea sediment deformation at the base of the Washington continental slope: A response to subduction. Geology, 2(11): 561-564.

Claypool, G. E., 1974. Anoxic Diagenesis and Bacterial Methane Production in Deep Sea Sediments. Ph.D. Thesis, Univ. Calif. Los Angeles, Calif., 276 pp.

Claypool, G. E. and Kaplan, I. R., 1974. The origin and distribution of methane in marine sediments. In: I. $R$. Kaplan (Editor), Natural Gases in Marine Sediments. Plenum, New York, N.Y., pp. 99-139.

Claypool, G. E. and Kvenvolden, K. A., 1983. Methane and other hydrocarbon gases in marine sediment. Annu. Rev. Earth Planet. Sci., 11: 299-327.

Drever, J. I., 1974. The magnesium problem. In: E. J. Goldberg (Editor), The Sea. Wiley, New York, N.Y., 5: 337-357.

Edmond, J. M., Measures, C., McDuff, R. E., Chan, L. H., Collier, R., Grant, B., Gordon, L. I. and Corliss, J. B., 1979. Ridge crest hydrothermal activity and the balances of the major and minor elements in the ocean: the Galapagos data. Earth Planet. Sci. Lett., 46: 1-18.

Garrels, R. M. and Mackenzie, F. T., 1971. Evolution of Sedimentary Rocks. Norton, New York, N.Y., 397 pp.

Grasshoff, K., 1976. Methods of Seawater Analysis. Verlag Chemie, Weinheim, New York, N.Y., 317 pp.

Han, M. W., 1987. Dynamics and Chemistry of Pore Fluids in Marine Sediments of Different Tectonic Settings: Oregon Subduction Zone and Bransfield Strait Extensional Basin. Ph.D. Thesis, Oregon State Univ.,Corvallis, OR, $280 \mathrm{pp}$.

Hart, S. R. and Staudigel, H., 1982. The control of alkalies and uranium in sea water by ocean crust alteration. Earth Planet. Sci. Lett., 58(2): 202-212.

Hartmann, M., Müller, P. J., Suess, E. and van der Weijden, C. H., 1973. Chemistry of late Quaternary sediments and their interstitial waters from the NWAfrican continental margin. "Meteor" Forsch. Ergebn., C-24: 1-67.

Holland, H. D., 1972. The geologic history of seawater an attempt to solve the problem. Geochim. Cosmochim. Acta, 36: 637-651.

Karlin, R., 1979. Sediment Sources and Clay Mineral Distributions off the Oregon Coast: Evidence for a 
Poleward Slope Undercurrent. M.S. Thesis, Oregon State Univ., Corvallis, OR, $80 \mathrm{pp}$.

Kastner, M., Suess, E., Garrison, R. E. and Kvenvolden, K., 1987. Hydrology, geochemistry and diagenesis along the convergent margin off Peru. EOS, 68(44): 1499.

Kawahata, H. and Fujioka, F., 1986. Sediments and interstitial water at Site 582 and 584, the Nankai trough and the Japan Trench landward slope. In: Initial Reports of the Deep Sea Drilling Project, Vol.87. U.S. Govt. Printing Office, Washington, D.C., pp. 865-875.

Krissek, L. A., 1982. Sources, dispersal, and contributions of fine-grained terrigenous sediments on the Oregon and Washington continental slope. Ph.D. Thesis, Oregon State Univ., Corvallis, OR, $226 \mathrm{pp}$.

Kulm, L. D. and Fowler, G. A., 1974. Oregon continental margin structure and stratigraphy: $A$ test of the imbricate thrust model. In: C. A. Burk and C. L. Drake (Editors), Geology of Continental Margins. Springer, New York, N.Y., pp. 261-283.

Kulm, L. D., Suess, E., Moore, J. C., Carson, B., Lewis, B. T., Ritger, S. D., Kadko, D. C., Thornburg, T. M., Embley, R. W., Rugh, W. D., Massoth, G. J., Langseth, M. G., Cochrane, G. R. and Scamman, R. L., 1986. Oregon subduction zone: venting, fauna, and carbonates. Science, 231: 561-566.

Kulm, L. D., Thornburg, T. M., Suess, E., Resig, J. and Freyer, P., 1988. Clastic, diagenetic, and metamorphic morphologies of a subsiding continental block: Central Peru forearc. In: E. Suess, R. von Huene and K. C. Emeis (Editors), Proc. Init. Reports (Part A) ODP 112, U.S. Govt. Print. Office, Washington, D.C., in press.

Le Pichon, X., liyama, T., Boulegue, J., Charvet, J., Faure, M., Kano, K., Lallemant, S., Okada, H., Rangin, C., Taira, A., Urabe, T. and Uyeda, S., 1987. Nankai trough and Zenisu ridge: a deep-sea submersible survey. Earth Planet. Sci. Lett., 83: 285-299.

Lerman, A., 1977. Migrational processes and chemical reactions in interstitial waters. In: E. D. Goldberg, I. N. McCave, J. J. O'brien, J. H. Steele (Editors), The Sea. Wiley, New York, N.Y., 6: 695-738.

Maris, C. R. P., Bender, M. L., Froelich, P. N., Barnes, R. and Luedtke, N. A., 1984. Chemical evidence for advection of hydrothermal solutions in the sediments of the Galapagos Mounds hydrothermal field. Geochim. Cosmochim. Acta, 48: 2331-2346.

McDuff, R. E., 1981. Major cation gradients in DSDP interstitial waters: the role of diffusive exchange between seawater and upper oceanic crust. Geochim. Cosmochim. Acta, 45: 1705-1713.

McDuff, R. E. and Gieskes, J. M., 1976. Calcium and magnesium profiles in DSDP interstitial waters: Diffusion or reaction? Earth Planet. Sci. Let., 33: 1-10.

Mehrbach, C., Culberson, C. H., Hawley, J. E. and Pytkowicz, R. M., 1973. Measurement of apparent dissociation constants of carbonic acid in seawater at atmospheric pressure. Limnol. Ocean., 18: 897-907.

Moor, G. W. and Gieskes, J. M., 1980. Interaction between sediment and interstitial water near the Japan Trench, Leg 57, In: Initial Reports of the Deep Sea Drilling
Project, Vol. 56/57. U.S. Govt. Printing Office, Washington, D.C., pp. 1269-1275.

Moore, J. C., Mascle, A., Taylor, E., Andrieff, P., Alvarez, F., Barnes, R., Beck, C., Behrmann, J., Blanc, G., Brown, K., Clark, M., Dolan, J., Fisher, A., Gieskes, J. and others, 1986. Structural and hydrologic framework of the northern Barbados ridge: results of Leg 110 ODP. International Kaiko Conference on Subduction Zones, 10-15 November, Tokyo and Shimizu, p. 25.

Ohta, S. and Laubier, L., 1987. Deep biological communities in the subduction zone of Japan from bottom photographs taken during "nautile" dives in the Kaiko project. Earth Planet, Sci. Lett., 83: 329 342 .

Pautot, G., Nakamura, K., Huchon, P., Angelier, J., Bourgois, J., Fujioka, K., Kanazawa, T., Nakamura, Y., Ogawa, Y., Seguret, M. and Takeuchi, A., 1987. Deep-sea submersible survey in the Suruga, Sagami and Japan Trenches: preliminary results of the 1985 Kaiko cruise, Leg 2. Earth Planet. Sci. Lett., 83: 300-312.

Plath, D. C., Johnson, K. S. and Pytkowicz, R. M., 1980. The solubility of calcite - probably containing magnesium - in seawater. Mar. Chem., 10: 9-29.

Pytkowicz, R. M., 1982. Equilibria, Nonequilibria and Natural Waters. Wiley, New York, N.Y., 351 pp.

Reck, B. H., 1987. Implications of measured thermal gradients for water movement through the northeast Japan accretionary prism. J. Geophys. Res., 92(B5): $3683-3690$.

Ritger, S., Carson, B. and Suess, E., 1987. Methane-derived authigenic carbonates formed by subduction-induced pore-water expulsion along the Oregon/Washington margin. Geol. Soc. Am., 98: 147-156.

Rubey, W. W., and Hubbert, M. K., 1959. Role of fluid pressure in mechanics of overthrust faulting. II. Overthrust belt in geosynclinal area of western Wyoming in light of fluid-pressure hypothesis. Bull. Geol. Soc. Am. 70: 167-206.

Russell, K. L., Deffeyes, K. S. and Fowler, G. S., 1967. Marine dolomite of unusual isotopic composition. Science, 155: 189-191.

Sayles, F. L., 1987. $\mathrm{CaCO}_{3}$ solubility in marine sediments: Evidence for equilibrium and non-equilibrium behavior. Geochim. Cosmochim. Acta, 49: 877-888.

Scamman, R. L., 1981. Diagenetic Carbonate Cementation of Clastic Sediments near the Sediment-Water Interface on the lower Continental Slope off Washington and northern Oregon. Thesis. Lehigh Univ., Bethlehem, Pa., $197 \mathrm{pp}$.

Schroeder, N. A. M., Kulm, V. and Muehlberg, G. E., 1987. Carbonate chimneys on the outer continental shelf: Evidence for fluid venting on the Oregon margin. Oreg. Geol., 49(8): 91-96.

Silver, E. A., 1972. Pleistocene tectonic accretion of the continental slope off Washington. Mar. Geol,, 13: 239-249.

Skirrow, G., 1975. The dissolved gases - carbon dioxide. In: J. P. Riley and G. Skirrow (Editors), Chemical Oceanography. Academic Press, New York, N.Y., pp. 1-197.

Stein, C. L. and Smith, A. J., 1986. Authigenic carbonate nodules in the Nankai trough, Site 583. In: Initial 
Reports of the Deep Sea Drilling Project, Vol. 87, U.S. Govt. Printing Office, Washington, D.C., pp. 659665.

Suess, E., Balzer, W., Hesse, K. F., Muller, P. J., Ungerer, C. A. and Wefer, G., 1982. Calcium carbonate hexahydrate from organic-rich sediments of the Antarctic shelf: Precursors of glendonites. Science, 216: 1128-1131.

Suess, E., Carson, B., Ritger, S. D., Moore, J. C., Kulm, L. D. and Cochrane, G. R., 1985. Biological communities at vent sites along the subduction zone off Oregon. In: M. L. Jones (Editor), The Hydrothermal Vents of the Eastern Pacific: An Overview. Bull. Biol. Soc. Wash., 6: 475-484.

Suess, E., Kulm, L. D., Carson, B. and Whiticar, M. J., 1987. Fluid flow and methane fluxes from vent sites at the Oregon subduction zones. EOS, 68(44): 1486.

Thompson, G., 1983. Basalt-seawater interaction. In: P. A. Rona, K. Bostrom, L. Laubier and K. L. Smith, Jr. (Editors), Hydrothermal Processes at Seafloor Spreading Centers. Plenum, Nato Conference Series, IV: 225-278.

Von Damm, K. L., Edmond, J. M., Grant, B., Measures, C. I., Walden, B., Weiss, R. F., 1985. Chemistry of submarine hydrothermal solutions at $21^{\circ} \mathrm{N}$, East Pacific Rise. Geochim. Cosmochim. Acta, 49: 2197-2220.

Von Huene, R., 1985. Direct measurement of pore fluid pressure, Leg 84, Guatemala and Costa Rica. In: Initial
Reports of the Deep Sea Drilling Project, Vol. 84. U.S. Govt. Printing Office, Washington, D.C., pp. 767-772.

Watermann, L. S., Sayles, F. L. and Manheim, F. T., 1972. Interstitial water studies on small core samples Leg 16, 17 and 18, In: Initial Reports of the Deep Sea Drilling Project, Vol. 18. U.S. Govt. Printing Office, Washington, D.C., pp. 1001-1012.

Weiss, R. F., 1974. Carbon dioxide in water and seawater: the solubility of a non-ideal gas. Mar. Chem., 2: 203215.

Weliky, K., Suess, E., Ungerer, C. A., Muller, P. J. and Fischer, K., 1983. Problems with accurate carbon measurements in marine sediments and particulate matter in seawater: A new approach. Limnol. Oceanogr., 28: $1252-1259$.

Wells, R. E., Engebretson, D. C., Snavely Jr., P. D. and Coe, R. S., 1984. Cenozoic plate motions and the volcanotectonic evolution of western Oregon and Washington. Tectonophysics, 3: 275-294.

Wiebe, R. and Gaddy, V. L., 1940. The solubility of carbon dioxide in water at various temperatures from 12 to $40^{\circ} \mathrm{C}$ at pressure to 500 atmospheres, critical phenomena. J. Am. Chem. Soc., 62: 815-817.

Wolery, T. J. and Sleep, N. D., 1976. Hydrothermal circulation and geochemical flux at mid-ocean ridges. J. Geology, 84: 249-275. 